Centre for Law, Economics and Society

CLES

Faculty of Laws, UCL

Director: Dr. Ioannis Lianos

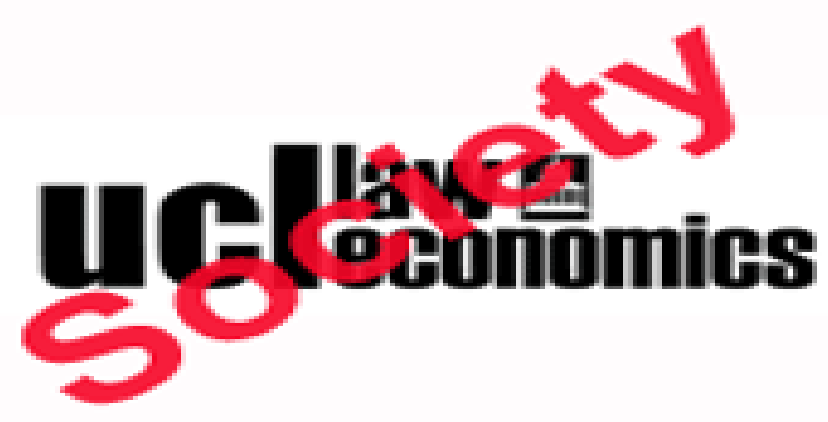

CLES Working Paper Series

$5 / 2012$

The emergence of forensic economics in competition law: foundations for a sociological analysis

\author{
Ioannis Lianos
}

September 2012 


\title{
The emergence of forensic economics in competition law: foundations for a sociological analysis
}

\author{
Ioannis Lianos
}

\section{Introduction}

The emergence of the role of forensic economics in competition law and policy the last four decades has been a major episode in the professionalization of economics and its increasing interaction with the legal sphere. Yet, there have only been very few studies examining from a sociological perspective the impact of forensic economics on the development of the research agenda of industrial economics and more generally the production of economic knowledge. The aim of this study is to critically examine how the emergence of forensic economics may impact on the production and evaluation of economic knowledge. The hypothesis to be investigated is that the production of economic knowledge, "in the context of application" (that is, "following the codes of practice relevant to a particular discipline and problem solving which is organised around a particular application"1) across a heterogeneous environment characterized by the presence of multiple institutions (e.g. Universities, government agencies, non-governmental organizations, private consultancies) affects the research agenda and the epistemic validity of the discipline of economics. The research will focus on an area of economics, with a significant "context of application", the field of applied Industrial Organization (IO) or competition economics. It will also concentrate on the analysis of the impact of private economic consultancies, as opposed to other institutions. The objective is to reflect on the theoretical foundations of a sociological analysis of forensic economics and more broadly on the relationship of academic economic "science" and economic science produced in the context of application (regulatory science), in this case economics applied in the field of competition law and policy. After examining the emergence of forensic economics as a separate field (2), we will examine the reality of forensic economics from the perspective of various theoretical approaches in sociology.

\section{The emergence of forensic economics}

\subsection{Topography: the field of forensic economics}

Forensic economics touches upon the relation between economics and the legal system. The interaction of the fields of law and economics is an old story ${ }^{2}$.

$1 \quad$ Michael Gibbons, Camille Limoges, Helga Nowotny, Simon Schwarztman, Peter Scott \& Martin Trow, The New Production of Knowledge (SAGE Publications, 1994), p. 3.

2 See, J. Walter Jones, Historical Introduction to the Theory of Law (Oxford, Clarendon Press, 1956), at 235-269; D. Hughes Parry, 'Economic Theories in English Case Law' (1931) 47 LQR 183 202. 
However, because of its profound interaction with the legal system and the core of economic thought, the field of forensic economics presents new challenges to the sociology of knowledge. It is thus important to distinguish forensic economics from other approaches that put law and economics in relation to each other.

One of these is the "law and economics" movement. Explicitly adopting an "external approach", this literature considers whether specific legal interventions are acceptable when assessed against an external, to law, criterion of validity. The "law and economics" scholarship advanced as a criterion the concept of economic efficiency, itself framed according to neoclassical economic theory and the idea of equilibrium, thus a principle entirely external and disconnected to the legal system. The interplay of law with economics acquired rapidly a normative interest as a research question, as economic concepts and methods were directly influential in reframing and in enriching legal discourse. Nevertheless, the opposite is not true: legal discourse did not influence the evolution of economic discourse. Indeed, the Coase theorem led to a certain degree of indifference to legal institutions in economic analysis, one of the basic tenets of the theorem suggesting that when transaction costs are low efficiency can be achieved through bargaining, without any contribution from the legal system ${ }^{3}$, hence, the ignorance by an important segment of the law and economics literature of the institutional environment of each jurisdiction.

The development of the "law and economics" movement as a "recognized sub-discipline" and research area in economics was made explicit by the publication in 1958 of the "Journal of Law and Economics" and the inclusion of the area of law and economics as item $\mathrm{K}$ in the "classification system for books" of the Journal of

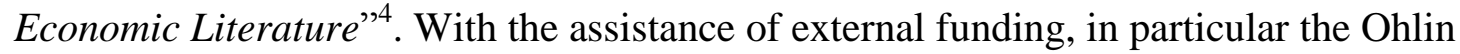
Foundation, the "law and economics" movement expanded from North America in the 1960s to Europe in the $1990 \mathrm{~s}^{5}$ and involved, for the first time within the same field, lawyers and economists, although one could easily remark the relative dominance of economists: the number of economists publishing Law and Economics studies is more than six times higher than the number of lawyers; in North America it is less than three times higher; the rate of participation of economists in law and economic journals is relatively similar in Europe, the United States and Canada. Lawyers' rates of participation differ substantially, ranging from 0.82 in Europe to more than four times that number in the United States and about forty times that number in Israel ${ }^{6}$.

\section{Figure 1: Participation in Authorship of Law and Economics Articles}

3 R.H. Coase, 'The Problem of Social Cost' (1960) 3 Journal of Law and Economics 1-44. This was not necessarily what R. Coase himself had in mind, as he had recognized elsewhere the importance of institutions in economic theorizing. R. H. Coase, 'The Nature of the Firm' (1937) 4 Economica 386-405. One should wait the new institutional school of economics for institutions to be again the subject of mainstream economic theory:

T. R. Ireland, 'The Interface between Law and Economics and Forensic Economics', (1997) 7 J. Legal Econ. 60, 60.

5 The European Association of Law and Economics has around 325 members

6 Oren Gazal-Ayal, "Economic Analysis of law in North America, Europe and Israel", (2007) 3:2 Review of Law and Economics 485. 


\section{Participation in Authorship of L\&E Articles \\ Source: Oren Gazal-Ayal, "Economic Analysis of law in North America, Europe and Israel", (2007) 3:2 Review of Law and Economics 485}

\begin{tabular}{llllllll}
\multicolumn{1}{c}{ Population (m) } & \multicolumn{3}{c}{ Country } & \multicolumn{2}{c}{ Number of participants } & \multicolumn{3}{c}{ Per 10M people } \\
& & Law & Econ & neither & Law & Econ & Neither \\
& & & & & & & \\
299.093 & USA & 106 & 258 & 18 & 3.54 & 8.62 & 0.60 \\
32.251 & Canada & 6 & 21 & 1 & 1.86 & 6.51 & 0.31 \\
7.109 & Israel & 22 & 13 & 0 & 30.94 & 18.28 & 0.00 \\
400.369 & Europe & 33 & 205 & 7 & 0.82 & 5.12 & 0.17 \\
10.481 & Belgium & 5 & 8 & 0 & 4.77 & 7.63 & 0.00 \\
5.425 & Denmark & 0 & 14 & 0 & 0.00 & 25.80 & 0.00 \\
61.004 & France & 0 & 22 & 0 & 0.00 & 3.61 & 0.00 \\
82.515 & Germany & 4 & 47 & 4 & 0.48 & 5.69 & 0.48 \\
11.275 & Greece & 3 & 12 & 1 & 2.66 & 10.64 & 0.88 \\
59.115 & Italy & 9 & 15 & 1 & 1.52 & 2.54 & 0.17 \\
16.386 & Netherlands & 4 & 18 & 0 & 2.44 & 10.98 & 0.00 \\
60.139 & UK & 5 & 23 & 1 & 0.83 & 3.82 & 0.17
\end{tabular}

According to Friedman, the economic analysis of law involves three distinct but related enterprises: the first is the use of economics to predict the effect of legal rules; the second is the use of economics to determine what legal rules are economically efficient, in order to recommend what the legal rules ought to be; the third is the use of economics to predict what the legal rules will be $\mathrm{e}^{7}$ The economists involved in the field of "law and economics" use the tools offered by price theory, welfare economics and public choice theory, which are also recognized subdisciplines of economics. To the difference, however, of the actors involved in these sub-disciplines, law and economic scholars are exclusively focusing on the study of substantive areas of the law, thus requiring the sharing of knowledge with legal scholars.

The field of "forensic economics" is of more recent occurrence. A ready-made definition of forensic economics is "the analysis of the participation of economists in the litigation process" $"$. The primary focus of forensic economics is the measurement and valuation of economic loss (damage) involving mainly personal injury, wrongful death, employment discrimination and commercial disputes ${ }^{9}$. Economists have also

$7 \quad$ David Friedman, The New Palgrave Dictionary of Economics (1987), vol. 3, p. 144.

8 T. R. Ireland, 'The Interface between Law and Economics and Forensic Economics', (1997) 7 Journal of Legal Economics 60, 60. Remark, however, the broader definition provided by E. Zitzewitz, Forensic Economics, February 2011, available at http://www.dartmouth.edu/ ericz/forensic.pdf , p. 1, distinguishing between the traditional definition of forensic economics as "the application of economics to the detection and quantification of harm from behaviour that has become the subject of litigation, and has been practiced by experts who are paid by the court or one of the parties" and "academic forensic economics" which "applies economics to detecting and quantifying behaviour" in order "to advance the general understanding of behaviour that is important to the functioning (or disfunction) of the economy".

See, for instance, M. Berenbult, Litigation Accounting: the Quantification of Economic Damages (Scarborough, Ontario: Carswell, 1995); R.L. Dunn, Recovery of Damages for Lost Profits (4 ${ }^{\text {th }}$ ed., Westport, CT: Lawpress, 1992); C.L. Knapp (ed.), Commercial Damages: A Guide to Remedies in Business Litigation (Matthew Bender, 1993); A.N. Link, "Evaluating Economic Damages: 
been used, albeit less frequently, for the purpose of determining the proof of liability: for example, in discrimination cases, antitrust (competition) law and public utility regulation ${ }^{10}$. Forensic economists are also concerned by "ethical issues involved in the twin roles of advocacy and computational neutrality by practitioners", the "rhetoric and limits of economic science", the "allocational impacts of various judicial doctrines relating to the character of allowable testimonial economic expertise and the development of solid procedures for interdisciplinary research leading to better estimation of damages" $"$.

"Forensic economics" should be distinguished from the "law and economics" movement for the following reasons.

First, forensic economics focus on issues of measurement and evidence, issues of expertise and the testimonial process, which are not topics within the traditional research agenda of the "law and economics" scholarship.

Second, law and economics constitutes "primarily an academic discipline, without a professional side that involved compensated participation in the litigation process" $"$. In contrast, "forensic economics grew out of a desire by professional economic consultants and expert witnesses to establish contact with each other to discuss common problems that were both professional and academic in nature"13. Thus, "(s)uspicion has existed among economists not involved in forensic work that forensic economists are in the business of developing testimonial uses of knowledge to make money, not to seek knowledge for its own sake, as it is generally the case in economics"14.

Third, one can clearly identify the tendency of forensic economists to organize themselves as a profession, which is certainly not a noticeable trend in the field of law and economics. For example, the National Association of Forensic Economics (NAFE), the first professional association of forensic economists, was founded in 1988. NAFE has members across the United States, in addition to some international members. Prior to the formation of NAFE, forensic economists acted as independent agents with relatively little intercommunication among practitioners. The main function of NAFE is to organize forensic economics' related events in major regional, national and international economic conferences. Its members receive information via quarterly newsletters and benefit from an Internet email group on forensic economics. The members of NAFE's Board are both academic and professional experts, although historically the Board has been mainly composed by academics. NAFE is publishing, since 1987, a specialised journal on forensic economics, the Journal of Forensic

A Handbook for Attorneys (Westport CT: Quorum Books, 1992); G. Martin, Determining Economic Damages ( $7^{\text {th }}$ ed., Santa Ana, CA: James Publishing, 1995); G.V. Smith and R. Parr, Valuation of Intellectual Property and Intangible Assets ( $2^{\text {nd }}$ ed., New York: Wiley, 1994); P.A. Gaughan and R. J. Thornton (eds.), Litigation Economics (Greenwich, CT: JAI Press, 1993).

10 Robert Thornton and John Ward, The Economist in Tort Litigation, (1999) 13(2) The Journal of Economic Perspectives, pp. 101-112, at 101.

${ }_{11}$ T. R. Ireland, op. cit. p.65.

12 Ibid.

13 Ibid.

$14 \quad$ Ibid., p. 67. 
Economics (JFE), which includes articles of interest to accountants, economists, finance and business professionals, lawyers in fields, such as business valuation, commercial litigation, torts and personal injury etc. NAFE is also publishing the Litigation Economics Digest/Review since 1995. The American Academy of Economic and Financial Experts (AAEFE) was formed and began arranging annual sessions in Las Vegas in 1989, within a rather informal setting ${ }^{15}$. The AAEFE publishes the Journal of Legal Economics, since 1991. The Board of AAEFE comprises both professional and academic experts. Finally, the American Rehabilitation Economics Association (AREA) is an association of vocational, economic and life care planning experts who evaluate the impact of injury for the purposes of trial. AREA organizes an annual conference and is publishing The Earnings Analyst, highlighting the latest industry research and trends. All the members of the Board of AREA are professional experts.

Of particular interest for our purposes is that both NAFE and AAEFE have published "ethics statements", attempting to protect "the integrity of the profession" through adherence to a number of tenets of ethical practice, such as that the experts "should decline involvement in any litigation when asked to take or support a predetermined position, when having ethical concerns about the nature of the requested assignment, or when compensation is contingent upon the outcome" and imposing a duty of disclosure ${ }^{16}$.

There have been several attempts to establish some form of certification of the profession of forensic economist. The efforts have been initiated by AREA, which put in place some form of registration process for forensic economists and established a certification for the position of Certified Earnings Analyst (CEA). The process is relatively informal and, at least for the registration as a forensic economist, requires some evidence of previous testifying activity and some form of peer review, although it is noted that this can be made via telephone if needed ${ }^{17}$. Both the NAFE and the AAEFE have opposed the attempts by AREA to certify forensic economists, the creation of the CEA position, which is not backed up by a formal state institutional mechanism of accreditation, being a compromise ${ }^{18}$.

It is thus possible to identify the emergence of a specific community of experts active in providing advice in litigation, sufficiently differentiated from the rest of the community of economists interacting with the legal system, the establishment of professional associations being the first step in the rise of a particular profession.

15 T.R. Ireland, Origins of the American Academy of Economic and Financial Experts, (20012002) 11 Journal of Legal Economics 82-87.

16 American Academy of Economic and Financial Experts, Statement of Ethical Principles, available at http://aaefe.org/Documents/AAEFE_Ethical_Principles.pdf . See also, for a similar effort, NAFE, Statement of Ethical Principles and Principles of Professional Practice, available at http://nafe.net/about-nafe/nafes-ethics-statement.html Note that the AAEFE has a stronger disclosure statement than NAFE, requiring that such disclosure "should be in sufficient detail to allow identification of specific sources relied upon and replication of the analytic conclusions by a competent economist with reasonable effort".

17 AREA procedures, available at http://www.a-r-e-a.org/downloads/procedures.pdf

18 T.R. Ireland, Origins of the American Academy of Economic and Financial Experts, (20012002) 11 Journal of Legal Economics, at 85. 
Nevertheless, these attempts have not led, for the time being, to the institutionalisation of a profession of "forensic economist", and have been opposed to by the three associations of forensic economists.

Fourth, contrary to the law and economics movement, which disposes of a clear research agenda, there are difficulties in defining a clear research programme for forensic economics. According to Brookshire,

"(f)orensic economists are themselves from disparate sub-disciplines of economics and they have always worked with those in the separate discipline of law." $"$.

Their different economic backgrounds might also impede the development of a uniform research agenda for the discipline. Brookshire notes that

"[...] this imbalance in research and analysis is because we are economists before we were forensic. Our academic prestige has been derived from our successes in the first area, rather than for our skills in the other" 20 .

One could indeed identify smaller communities of forensic economic experts which present different characteristics from each other, depending on the areas of their consulting activity. Of particular interest for the purpose of our research question is the development of forensic economics in the area of industrial organization and, more specifically, competition economics.

\subsection{Competition economics and applied IO as a subfield of forensic economics}

A quick look to the articles published in the two main journals on forensic economics show that studies on the application of forensic economics in antitrust/competition law are rare $^{21}$.

Figure 2: Number of articles on competition economics in forensic economic journals

\begin{tabular}{|l|l|l|}
\hline Issues period & $\begin{array}{l}\text { Number of Articles } \\
\text { Journal of Forensic Economics }\end{array}$ & $\begin{array}{l}\text { Number of Articles } \\
\text { Journal of Legal } \\
\text { Economics }\end{array}$ \\
\hline $1987-1990$ & 0 & Journal not established \\
\hline $1991-1994$ & 0 & 3 \\
\hline
\end{tabular}

19 M. Brookshire, An Agenda for Future Research in Forensic Economics, (1991) 4(3) Journal of Forensic Economics 287-296, pp. 294-295

20 Ibid., p. 295

21 See also, M.P. Schinkel, Forensic Economics in Competition Law Enforcement, (2008), available at http://papers.ssrn.com/sol3/papers.cfm?abstract id=1009573 , noting that "the vast majority of the papers published in the volumes of the Journla of Forensic Economics is on the quantification of damages in individual tort cases. Topics include the appropriate discount rate, expected employment duration and the effects of progressive taxes in present value calculations of lost earning as a result of personal injury and wrongful death. Typically, causality in these accident cases is straightforwardly established and has nothing to do with economics. Only a hand-full of papers discusses applications of economics to competition cases". 


\begin{tabular}{|l|l|l|}
\hline $1995-1998$ & 1 & 0 \\
\hline $1999-2002$ & 0 & 0 \\
\hline $2003-2007$ & 1 & 1 \\
\hline $2008-2011$ & 0 & 0 \\
\hline
\end{tabular}

The combined areas of damage analysis for personal injuries and wrongful deaths constitute the majority of research done in the area of forensic economics. However, it has been noted that

"(i)n terms of published research and papers presented, antitrust law and the role economists play in antitrust litigation, while technically included within any reasonable definition of forensic economics, is really a subfield unto itself within the area of industrial organization rather than either forensic economics or law and economics",22.

Publications in the area of competition economics (also empirical studies) usually appear in specialised journals in competition law and policy, with a mixed audience of lawyers and competition economists, or in mainstream economic journals ${ }^{23}$. Competition economists have also established their own academic association, the European Association of Competition Economists (ACE), with a mixed academic, regulatory and professional consultants' membership ${ }^{24}$. There is no equivalent association in the United States. There seem to be very few links between the members of the ACE and those of NAFE and AAEFE, and more broadly other groups of forensic economists. The very few publications on forensic economics in competition law focus only on competition economics and do not attempt to establish any serious linkage with the broader literature on forensic economics ${ }^{25}$. Forensic competition economics specialists are almost uniquely specialised in price theory and industrial organization (IO), thus the area is much less diverse than the broader field of forensic economics ${ }^{26}$.

An important difference with the rest of the forensic economics community is that forensic competition economists or forensic IO experts are not only concerned with the assessment of damages, as it is usually the case for forensic economics, but

"make some of its most fundamental contributions to competition cases by assisting to establish causality [...] To determine likely causalities requires a

22 T.R. Ireland, Origins of the American Academy of Economic and Financial Experts, (20012002) 11 Journal of Legal Economics, at 65.

23 To complete

24 See, http://www.competitioneconomics.org/ The steering committee for 2011 is composed by three professional consultants, three academic economists and three regulatory economists. The three constituencies are also equally represented at the executive of the Association.

25 See, J.M Connor, Forensic Economics : An introduction with special emphasis on price fixing, (2006), available at http://papers.ssrn.com/sol3/papers.cfm?abstract id=988709 ; MP Schinkel, Forensic Economics in Competition Law Enforcement, (2008), available at http://papers.ssrn.com/sol3/papers.cfm?abstract_id=1009573. More generally, see

See ibid, referring invariably to competition economics or forensic IO. 
complex process of building a relevant economic theory, deriving testable hypotheses, and corroborating them with the help of econometric tests"27.

The structure of the industry is another important distinguishing factor. In their recent studies on the development of forensic competition economics in Europe and in the Unites States, Damien Neven ${ }^{28}$ and Jon Baker ${ }^{29}$ note the increasing importance of forensic economic evidence in several steps of competition law litigation. Neven includes a rare analysis of the emergence of a market for economic advice in the area of competition law. He notes that

" (w)ith the implementation of the merger regulation in 1990, demand for economic advice seems to have risen. NERA opened an office in London in 1984 and London Economics was set up in 1986. Lexecon (Ltd) was set up in January 1991 and up until the mid nineties, Lexecon, London Economics and NERA were the main suppliers with a total amount of fees around $£ 2.5$ million in 1995. This turnover corresponds to EU related competition work but also to competition work in national jurisdictions. UK related work accounts for the vast majority of the latter. The market for EU related advice grew rapidly in the late nineties, as the number of merger notifications (as well as other types of cases) grew but also following the preparation and implementation of the notice on market definition [adopted by the European Commission]. This notice, inspired by the US practice, used economic concepts explicitly. [... [ For the following ten years, total turnover grew at some $25-30 \%$ per year, reaching about $£ 24$ million in 2004 "30.

These estimations are based on the assumption that economic consultancy fees would amount to about $15 \%$ of the total amount of legal fees, this percentage being more or less similar in Europe and in the US. Connor notes that antitrust economic consulting in the US must have exceeded $\$ 800$ million per year in the late $1990 \mathrm{~s}^{31}$. The industry has also moved towards global consolidation with a small number of global consultancy firms with operations in Europe and in the United States and some smaller boutique firms in important national jurisdictions. Neven observes that

"( $\mathrm{t}$ )he market structure is [...] characterized by the presence of three firms with global (or at least transatlantic) operations. In this respect, economic consultancy seems to have followed the same path as legal advice, both moves being triggered by clients with operations and antitrust filings across jurisdictions" 32 .

An important factor to take into account is also the parallel development of market structures for economic consultancies active in competition economics advice and multinational law firms. Although the activities of economic consultancies

\footnotetext{
27 MP Schinkel, Forensic Economics in Competition Law Enforcement, (2008), above, at p. 7.

28 D. Neven, Competition Economics and antitrust in Europe, (2006) Economic Policy 741-781.

29 J.B. Baker, The Case for Antitrust Enforcement, (2003) 17(4) Journal of Economic Perspectives, 27-50.

30 D. Neven, Competition Economics and antitrust in Europe, above, at p. 6.

31 J.M Connor, Forensic Economics : An introduction with special emphasis on price fixing, (2006).

Ibid., at p. 7.
} 
encompass a large number of areas, such as securities regulation and financial markets, valuation and financial analysis, bankruptcy and financial distress litigation, IP law and the assessment of damages in commercial and civil litigation, the area of antitrust/competition economics (forensic IO) has been traditionally one of the major practices and certainly the one that has permitted these consultancies to grow and to establish links with the major international law firms that form its main client base.

Figure 3 : Areas of activities of the main economic consultancies

\begin{tabular}{|l|l|l|l|l|l|}
\hline & $\begin{array}{l}\text { Compass } \\
\text { Lexecon }\end{array}$ & CRAI & RBB & $\begin{array}{l}\text { Frontier } \\
\text { Economics }\end{array}$ & NERA \\
\hline Antitrust-Competition & $\mathrm{X}$ & $\mathrm{X}$ & $\mathrm{X}$ & $\mathrm{X}$ & $\mathrm{X}$ \\
\hline $\begin{array}{l}\text { Securities regulation } \\
\text { financial markets }\end{array}$ & $\mathrm{X}$ & $\mathrm{X}$ & & $\mathrm{X}$ & $\mathrm{X}$ \\
\hline Employment discrimination & $\mathrm{X}$ & $\mathrm{X}$ & & & $\mathrm{X}$ \\
\hline $\begin{array}{l}\text { Bankruptcy and financial } \\
\text { distress litigation }\end{array}$ & $\mathrm{X}$ & $\mathrm{X}$ & & $\mathrm{X}$ \\
\hline $\begin{array}{l}\text { Civil litigation - breach of } \\
\text { contracts/torts damages }\end{array}$ & $\mathrm{X}$ & $\mathrm{X}$ & & & $\mathrm{X}$ \\
\hline $\begin{array}{l}\text { Regulatory (telecoms, } \\
\text { energy, auctions etc) }\end{array}$ & $\mathrm{X}$ & $\mathrm{X}$ & $\mathrm{X}$ & $\mathrm{X}$ & $\mathrm{X}$ \\
\hline $\begin{array}{l}\text { International } \\
\text { Arbitration/Litigation/Class } \\
\text { certification }\end{array}$ & $\mathrm{X}$ & $\mathrm{X}$ & & $\mathrm{X}$ & $\mathrm{X}$ \\
\hline IP Law & & & $\mathrm{X}$ & \\
\hline Corporate Governance & $\mathrm{X}$ & $\mathrm{X}$ & & & $\mathrm{X}$ \\
\hline Environmental regulation & & & & & \\
\hline
\end{tabular}

The history of NERA (National Economic Research Associates), one of the first microeconomic consulting firms, illustrates the importance of antitrust and competition litigation in the development of this industry.

The rise of NERA as an example of the emergence of a micro-economic consulting firm

NERA was founded in 1961 by two professional economists with the advice of Alfred Kahn, a well known academic economist who has been active in government by heading in the late 1970s the efforts to deregulate the airline industry. NERA started as a small US based firm with 17 employees based in its two offices (in New York City and Washington DC). It was "the first consulting firm dedicated to methodically applying rigorous microeconomic thought to litigation and regulatory matters" ${ }^{33}$. The

33 NERA website, available at http://www.nera.com/7250.htm 
firm's economists initially worked on projects including natural gas field pricing matters, particularly oil well-head price controls and provided testimony before state and federal US regulatory authorities in the utilities sector. Soon, the work of NERA extended to antitrust (competition law) matters, in particular in view of the long term relations that NERA managed to establish with key industry players requiring its economic advice, such as AT\&T. In 1968, the firm was for the first time involved in securities regulation work, acting as consultants for the New York Stock Exchange (NYSE), thus expanding its expertise from Industrial Organization issues to financial economics. As a result of the increasing workload, linked to the expansion of the use of economics in antitrust and regulatory matters, the firm expanded in the US in the 1970s, opening offices in Los Angeles in 1974. The deregulation process in energy markets and other major industries in the late 1970s greatly enhanced the work of the company, which acted advising both companies and a number of regulators and governments, in such diverse areas as the oil industry, communications, shipping, transportation, postal rate economics, airlines, consumer products, television and newspapers, and sports economics. In 1972, the firm also expanded its work in employment discrimination cases. The increasing amount of work in certain areas led NERA to establish formal practices (departments) within the structure of the company, in particular in the areas of antitrust, energy and communications regulation. The company was involved for the first time in an environmental law case in 1978, on the calculation of damages to natural resources and cost/benefit studies on environmental pollution. According to NERA's website, NERA's “prominence in antitrust led the firm to hold its first annual Antitrust Seminar in Aspen, Colorado, in July 1979", which continues to bring together regulators, antitrust practitioners, and NERA economists. The firm formally established its Securities and Finance Practice in 1987. The spread of the deregulation movement beyond the US in the 1980s led to the international expansion of NERA, which opened its first non-US office in London in 1984, largely to assist the UK government with matters related to privatization. In the late 1990s, NERA had grown to more than 400 members, including 300 consulting economists. The early 1990s is also the period when NERA developed its Mass Torts and Product Liability Practice and IP litigation practice. The firm further expanded its presence internationally opening offices in Madrid, Spain (1990), Sydney, Australia (1998), Brussels (2000), Tokyo and Rome (2001), Paris (2003), Frankfurt (2004), Shanghai and Melbourne, Australia (2006), Beijing, Geneva, Auckland and Wellington, New Zealand (2008). NERA now operates 20 offices around the world. In 2004, NERA founded its London-based Competition Policy Practice, thus illustrating the importance of the competition economics practice as a specific field of forensic economics. According to information provided in NERA's website, NERA is planning to expand its activities to new competition law jurisdictions, such as India, Singapore, Hong Kong, Brazil, and South Africa, thus illustrating the multinational dimension of commercial and trade law disputes. 
Notwithstanding the expansion of forensic economics to a variety of areas, the corporatisation of forensic economics, with the emergence of multinational economic consultancies specialised in support services for litigation, is more pronounced in the area of applied IO to competition and regulatory litigation, than in other areas of practice. This accentuates the important differences that we have previously identified with regard to the self-perception of competition economists as a separate community from other forensic economists.

A possible explanation for this different self-perception is the integration of economists in the state bureaucracies involved in the enforcement of competition law, in comparison with their relative minor role in other areas, such as environmental regulation, employment discrimination, IP law etc. Neven noted that in 2004 there were 83 professionals with a background in economics and around 184 with a background in law (hence roughly a ration of 1 to 2 ) at the European Commission, this ratio being 1 to 7 in the early 1990s. To this, one could add the establishment in 2003 of the position of chief economist of the European Commission with a team consisting of $10-15 \mathrm{PhD}$ economists. Neven estimates that there were a little more than 150 professional economists working with economic consultancy firms in the area of competition economics in 2004 and more than 100 professional economists working with the US Department of Justice Antitrust Division and the US Federal Trade Commission. The expansion of economic consultancies worldwide and the increasing recruitment of economists by a number of national competition authorities in Europe, Asia, Latin America and Oceania during the last five years may put the figure of forensic economists, working in the private sector or governmental bureaucracies to a figure between 3000 and 4000 individuals $^{34}$. The multiplication of economists working in regulatory agencies, in particular competition authorities has not occurred to the same extent in other areas of law, where generalist courts constitute the main enforcement engines and regulatory authorities are staffed mainly by lawyers.

\subsection{The link between the communities of practice and theory: forensic IO and academic economists}

We will focus on the specific community of forensic IO economists working in antitrust/competition law litigation, exploring how this community interrelates with the community of academic economists in the area of Industrial Organization. We will highlight, first, their role in competition law litigation and, secondly, the issues this might raise with regard to the interaction between forensic economists and lawyers and between forensic economists and academic economists.

\footnotetext{
34 According to the some rough calculations by the author. This is based on the fact that the Antitrust Section of the American Bar Association had in recent years an average membership of 15000 , many of which are economists, assuming that $15 \%$ of the legal fees are used to hire economic consultants.
} 


\subsubsection{Forensic IO economists and their contribution to legal practice}

The increasing influence of economic discourse (Industrial Organization) on competition law is well documented. The main tenets and principles of competition law witnessed a profound transformation with the systematic recourse to neoclassical price theory as an external source of authority for competition law. More than in any other field of law, except perhaps the related area of public utilities law, competition law is intrinsically linked with the discipline of economics, as this is shown by the frequent references to economic concepts and methodology of competition authorities, the case law of the courts and the expanding soft law relating to the interpretation of the competition law statutes. A common feature of this transformation of competition law is the emphasis put on a, mostly synchronic, analysis of the welfare effects of the specific commercial practice on consumers or more broadly economic efficiency. This is the main thrust of the "more economic" "effects-based approach" that has gained momentum in the US before being transposed to European competition law and more recently to new competition law jurisdictions, such as China, India etc.

An important part of the evidence presented in competition law disputes is of economic nature, such as econometric techniques and economic models. Consulting economists have acted as witnesses in US antitrust trials since at least the 1920s, but commonly only since the 1960s. Connor relates that the first refereed economic journal articles explaining some of the methods used by economists in antitrust litigation were published in the late $1960 \mathrm{~s}$ and $1970 \mathrm{~s}^{35}$.

Forensic IO is relevant in all steps of antitrust litigation, either in front of regulatory authorities or presented in courts. First, at the detection and investigation phases, forensic IO can help to uncover recognized types of antitrust violations by systematically screening industries and firms as well as by assisting the antitrust agencies to actively discover and assess the illegality of certain business strategies ${ }^{36}$. Second, the main function of forensic IO is the building of the economic logic of a case. Assessing the existence of market power through the application of the SSNIPtest for the determination of the relevant market, HHI calculations for merger assessments, the Elzinga-Hogarty-test for market delineation have become standard procedures in enforcing competition law in an array of jurisdictions. Third, forensic IO may assist in determining appropriate remedies in cases in which an antitrust concern or an infringement has been established, including the quantification of damages and the design of an effective private enforcement practice.

Economic evidence may take different forms: economic theory and models or quantitative econometric studies. The following table illustrates the importance of quantitative econometric methods in competition law enforcement in recent years.

\footnotetext{
35 J.M Connor, Forensic Economics : An introduction with special emphasis on price fixing, (2006).

36 MP Schinkel, Forensic Economics in Competition Law Enforcement, (2008), above, at p pp. $8-9$.
} 
Figure 4: Quantitative techniques in merger control in EU competition law

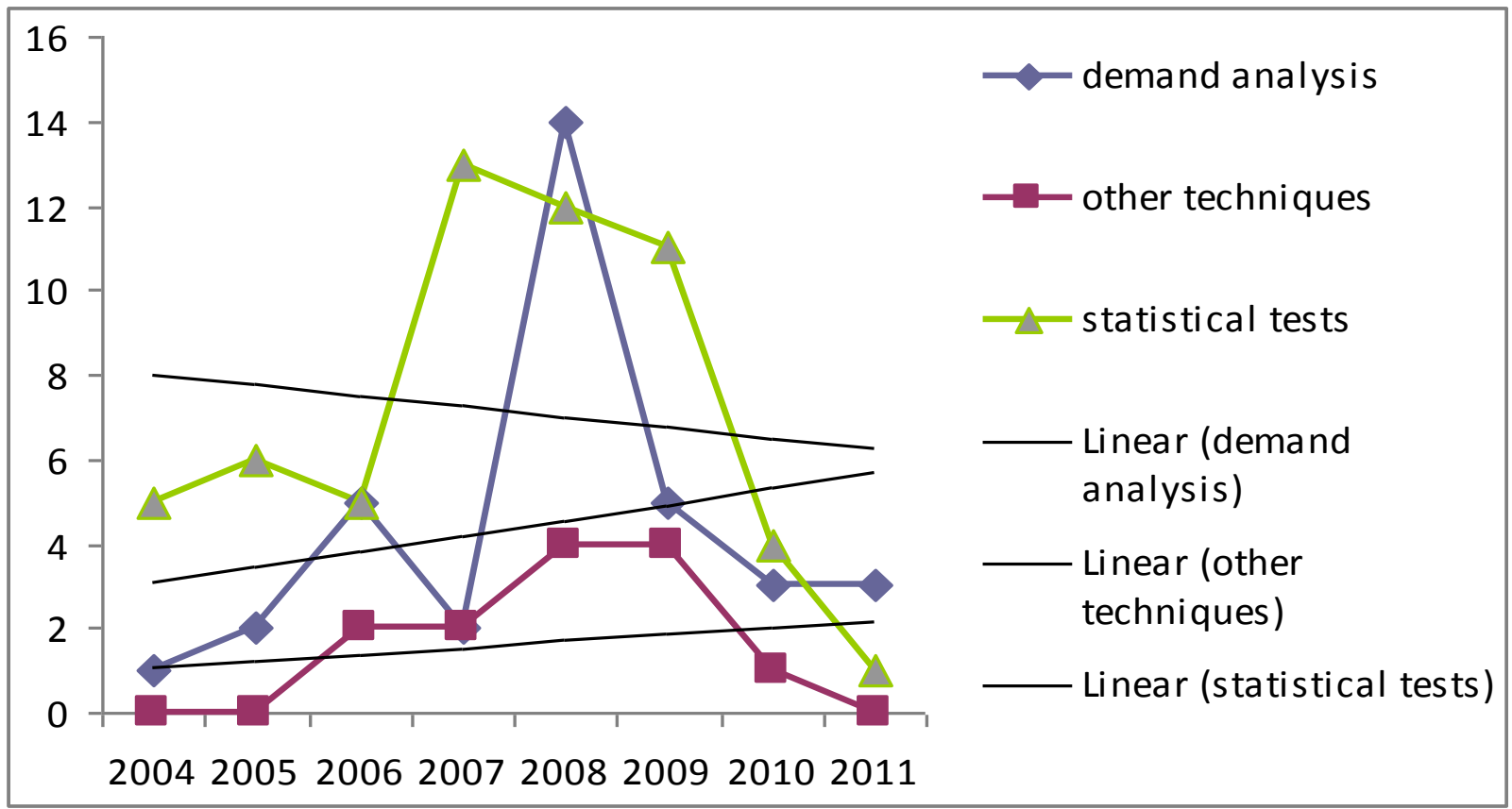


However, forensic IO is not only relevant for the adjudication of evidence in specific competition law disputes but is also contributing to legal hermeneutics with the incorporation in law of "economic transplants". This term refers to any concept of economics that has been incorporated into the legal discourse by an act of translation performed by an organ vested with the authority to adjudicate and capable therefore of producing an impact on the interpretation of legal norms. Economic transplants are essential intermediary steps in the process of qualification of the facts of a competition law case, but also, in some circumstances, provide content to the text of the law (market power, barriers to entry, consumer welfare, efficiency gains). In competition law, economic transplants were predominantly integrated by the instrument of soft law (Guidelines) ${ }^{37}$. This followed the path of US antitrust law. Starting with the 1968 Guidelines on Merger Enforcement, US antitrust law integrated different economic concepts that became influential in framing antitrust law discourse in courts and consequently led to the development of forensic $\mathrm{IO}^{38}$.

Hillary Greene's important study on the institutionalization of US merger guidelines in antitrust discourse provides an excellent example of the integration of economic transplants through the instrument of guidelines ${ }^{39}$. Greene gives the example of concentration measures in merger control in order to illustrate the impact of the guidelines. Prior and shortly after the 1968 US Guidelines on merger control, the Courts employed the four-firm (CR4) concentration measure in merger analysis, representing the sum of the market shares for the four largest firms in the market ${ }^{40}$. In 1982, the DOJ revised its 1968 guidelines and introduced a new measure of concentration, the Herfindahl-Hirshman Index (called HHI), which is the sum of the squares of the market shares of the firms present in that market ${ }^{41}$. Hillary Greene observes that the HHI index was discussed in economic circles, since at least the early $1960 \mathrm{~s}^{42}$, when George Stigler published his seminal work on oligopoly theory ${ }^{43}$, and that it "became part of the mainstream legal literature" following the suggestions of the law professor, then judge, Richard Posner ${ }^{44}$. She observes, however, that the case law on Section 7 of Clayton Act (the US merger statute) has ignored the HHI index

37 Ph. Areeda, 'Justice's Merger Guidelines: The General Theory’ (1983) California Law Rev $303-310$.

38 The 1968 Guidelines were the intellectual child of Donald Turner, the first $\mathrm{PhD}$ economist to be appointed Assistant Attorney General for Antitrust and a key figure in the re-orientation of antitrust law in the US towards an economic approach in the 1960s. See, O. Williamson, 'The Merger Guidelines of the US Department of Justice - In Perspective' available at http://www.usdoj.gov/atr/hmerger/11257.htm\#N_1_(last accessed July 18, 2009).

39 H. Greene, 'Guideline Institutionalization: The Role of Merger Guidelines in Antitrust Discourse' (2006) 48(3) William \& Mary L Rev 771-857.

40 U.S. Dep't of Justice, Merger Guidelines-1968, reprinted in 4 Trade Reg. Rep. (CCH) II 13,101 (May 20, 1968).

${ }_{41}$ U.S. Dep't of Justice, Merger Guidelines-1982, reprinted in 4 Trade Reg. Rep. (CCH)I 13,102 9June 14, 1982).

$42 \quad$ H. Greene, above n, at 788.

43 G. Stigler, 'A Theory of Oligopoly' (1964) 72(1) Journal of Political Economy 44-61, at 59.

44 R.A. Posner, 'Oligopoly and the Antitrust Laws: A Suggested Approach', (1969) 21(6)

Stanford L Rev 1562-1606, at 1602-1603. 
until the 1982 Guidelines were adopted ${ }^{45}$. Prior to that date, case law was written almost entirely in terms of CR4 or other concentration ratios. Immediately after the adoption of the 1982 Guidelines, a transition period started during which both CR4 and HHI concentration measures were relied by the courts, although the later gained progressively a more important role ${ }^{46}$. She also notes the important increase of the rate of references to the guidelines since the early 1970s. In conclusion, the adoption of new version of Guidelines profoundly influenced the direction of the case law (hard law). According to Greene,

"from around $10-15 \%$ in the 1970 s the reference rate increased to $15-20 \%$ in the late 1970s and early 1980s. In 1983 shortly after the adoption of the 1982 Guidelines were issued, the reference rate increased to above $50 \%$ and by the late 1980s the rate averaged $60 \%$ or higher. After the 1982 Guidelines were issued, merger guidelines quickly became the "basic reference point" in section 7 Clayton Act rulings $" 47$.

As a consequence of the increasing relevance of economic evidence in competition law cases, the role of forensic economists is now pivotal in competition litigation. Evidence is often presented by experts employed by parties and providing advice on the economic merits of the case representing persistent communities of practice outside the legal domain ${ }^{48}$.

\subsubsection{The influence of external (legal) factors in the production and evaluation of economic knowledge}

As it has been noted by some academic commentators, "the law today not only interprets the social impacts of science" but also "constructs" the very environment in which scientific discourse comes to have "meaning, utility, and force" 49 . Economic research completed "in the context of application" is conducted and interpreted to answer legal questions; the content of scientific knowledge is shaped in a complex social process, which includes the legal sub-system as well as the economic scientific discourse. Judicial decision-making exercises also an important influence on the definitions of "good science", therefore affecting at the same time the content and the direction of economic discourse.

An illustration of the profound interaction between legal and economic discourse is the emergence of economic "schools of thought", as a way to conceptualize and rationalize ex post legal doctrine and authority in the area of competition law. There is a lot of literature recently on the question of the dominant "school" of economic thought that is followed by the Supreme Court of the United States. Professor Einer Elhauge from Harvard University has recently published an

\footnotetext{
$45 \quad$ H. Greene, above n, at 789.

46 Ibid., at 790-791.

47 Ibid., at $802-803$.

48 Déirdre Dwyer, The Judicial Assessment of Expert Evidence (Cambridge Univ. Pres, 2008), at

76.

Sheila Jasanoff, Science at the Bar (Harvard Univ. Press, 1997), at 16.
} 
article entitled "Harvard, not Chicago: Which Antitrust School Drives Recent Supreme Court Decisions?", implying that there is a dominant "school" of economic thought that provides its conceptual guidance to the antitrust jurisprudence of the US Supreme Court. After examining the 14 most recent cases of the Supreme Court in antitrust professor Elhauge argues that

"the Supreme Court has sided with the Harvard School... It has also sided with sound economic analysis to resolve antitrust issues, rather than a resort to either the old formalisms that favored plaintiffs, or new formalisms that try to favor defendants" $"$.

Professor Joshua Wright from George Mason University argues exactly the opposite:

"the Roberts Court decisions embrace the Chicago School of antitrust analysis

and predict that the antitrust jurisprudence of this Court will increasingly reflect this influence" $" 51$.

These are non-exhaustive examples of the growing antitrust law and economics schools-related literature in antitrust. ${ }^{52}$ If explanatory features of economic discourse, such as schools of economic thought, become also explanatory features of legal discourse, there is a point to make on the profound interaction and mutual influence between the two spheres. But how this process occurs?

A possible explanation is the existence of a hybrid competition law community formed by lawyers and economists that is in constant communication, either in the practical aspect of competition law enforcement or in the more theoretical aspect of competition law doctrine. However, this does not explain why only certain schools of economic thought seem to attract the interest of competition law doctrine and not others. One could argue that this is linked to the fact that only specific schools of economic thought have been attentive to the issue of competition. This is certainly not a satisfactory response: for example, there is a distinct Marxist theory of competition, which, for different reasons has never made it to the courtrooms and has never attracted the attention of competition law discourse ${ }^{53}$. An alternative explanation may be that some of the members of the economics community benefit from a privileged access to the legal community in competition

50 Einer Elhauge, "Harvard, not Chicago: Which Antitrust School Drives Recent Supreme Court Decisions?", (2007) 3(2) Competition Policy International, available at http://papers.ssrn.com/sol3/papers.cfm?abstract_id=1010769, at 1.

$51 \quad$ Joshua Wright, "The Robert Court and the Chicago School of Antitrust: The 2006 term and beyond", (2007) 3(2) Competition Policy International,available at http://www.globalcompetitionpolicy.org/index.php?\&id=582\&action=907

52 The focus is almost on the same schools: Harvard, Chicago, post-Chicago, but also includes in Europe the ordo-liberal school (see for example the analysis of Alberto Pera, "Changing Views of Competition, Economic Analysis and EC Antitrust Law", (2008) European Comp J 127). One could also add studies exploring the influence of new-institutional and Austrian economics in competition law (see, for new institutional economics, Ioannis Lianos, Commercial Agency Agreements, Vertical restraints and the Limits of Article 81(1): Between Hierarchies and Networks [2007] 3(4) Journal of Competition Law and Economics 625-672; Dina Kallay, The Law and Economics of Antitrust and Intellectual Property - An Austrian Approach, (Edward Elgar, 2004).

$53 \quad$ See, Anwar Shaikh, 'Competition and Industrial Rates of Return', in Philip Arestis \& John Eatwell (ed.), Issues in Finance and Industry - Essays in Honour of Ajit Singh (Palgrave Macmillan, 2008) pp 167-194. 
law, therefore being able to pass their specific message on the relevant and adequate economic discourse that should underpin legal discourse. This hypothesis, which needs to be empirically verified, builds on the observation that economists that are in constant communication with competition lawyers in enforcing competition law influence the perception, by these lawyers, of the content of economic discourse. The increasing role of economic consultancies and forensic economics in competition law and policy illustrates the profound interaction between these different actors/agents and the constitution of specific sub-communities. The emergence of a market for economic experts in Europe illustrates the development of forensic economics or applied antitrust economics as a specific field of economic enquiry. Competition law experts are also highly specialised and are intensive users of economic reasoning, even in areas outside the close realm of competition law.

My hypothesis assumes that there are two distinct sub-communities in industrial organization (IO) economics: forensic economists and academic economists and that the respective influence of schools of economic thought may be different in each of these two communities. The distinction between purely academic economists and forensic economists is not something specific in economics. Krohn distinguished three types of research situations, depending on the reward structure and the time spent for non-research activities:

1. "Academic basic research: scientist were hired to perform limited nonresearch duties, and obtained outside support for (presumably) theoretical research of their own choice.

2. Open-applied research: scientists were hired to perform limited nonresearch duties and obtained outside support for (presumably) practical research of their own choice.

3. Bound-applied research; scientists were hired to work full-time on problems related to the purposes of their employing organizations"

Forensic economists are situated across the pole that goes from "bound-applied research" to "open-applied research", as some of them are also active academics, while academic economists concentrate at the pole of "academic basic research", with some being occasional consultants and thus included in the "open-applied research" category. The intermediary category of academics that are also acting as forensic economists is of particular importance for our study, as they might act as communicators of the values of each pole to the other.

This distinction needs to be established empirically, for example by examining the representation of each school of economic thought, as identified by the fact that the members of this "school" or "network" share common beliefs, in the subcommunities of forensic economists and academic economists, as well as by identifying situations where there is a significant gap of representation for a school in each sub-community. In other words, the research will measure the distribution of specific beliefs within each community. The distinction between forensic and 
academic economists also assumes that the mode of operation of each sub-community is different.

Based on the work of Robert Merton on the reward system of open science, based on priority, one could argue the specificity of the academic community of economists with regard to community of forensic economists, which is not marked by openness (there is an inherent bias that only the results that could be positive to the client are publicly shared $)^{55}$. Furthermore, the structure of rewards is different. In essence, the reward system in science is managed by the scientific community itself. This does not exclude the intervention of the market mechanism, but at a second stage, after the social reward structure of collegiate science took place, "picking up" the disclosed knowledge or information brought in by the open science phase in order to develop new products and services ${ }^{56}$. Dasgupta and David have clearly shown that changes brought to the underlying reward system of science will have particular implications on the "autonomy" of the scientific process, "in the sense of the scientific community's self governance and control over the research agenda" ${ }^{, 57}$. Others, like Wible have developed a complements view of the organization of the scientific process, with market and nonmarket institutions being separate institutions but also fulfilling the "dual nature of the scientific enterprise": a unique non market structure and a "secondary science" relying on markets ${ }^{58}$. Wible emphasizes the need to preserve this institutional and epistemic diversity:

"a variety of qualitatively differentiated organizations are essential for resolving epistemic scarcity. Humanity cannot depend on just one institution like the market or even the primacy of one institution among others. We cannot pull all our organizational 'eggs' into one institutional basket"59.

Calls for epistemic diversity have also been recently made in competition law economics literature. Oliver Budzinski, among others, has highlighted the risks of "monoculture" in competition economics and proposed "theory pluralism" of competition policy paradigms as being an essential prescription for public policy in this area ${ }^{60}$. Budzinski's argument must be understood in the context of the debate over the need or not to harmonize competition law globally. His contribution attempts to demonstrate the benefits of a decentralised approach. However, his most recent formulation of the pluralism argument goes further than that. After exposing the basic tenets of different competition theories and policy programs (classic and neoclassic price theory, Harvard, Chicago and post-Chicago schools, German ordoliberalism,

55 Robert Merton, The Sociology of Science: Theoretical and Empirical Investigations (University of Chicago Press, 1979), Chapter 4.

$56 \quad$ D. Wade Hands, Reflection without Rules (CUP, 2001), at 377.

57 Partha Dasgupta \& Paul A. David, 'Towards a New Economics of Science', (1994) 23 Research Policy 487, at 505.

$58 \quad$ James R. Wible, The Economics of Science: Methodology and Epistemology as if Economics Really Mattered (Routledge, London, 1998), at 172.

$59 \quad$ Ibid., at 174-175.

60 Oliver Budzinski, 'Pluralism of Competition Policy Paradigms and the Call for Regulatory Diversity', N014/2003, Volkswirtschaftliche Beiträge, Marburg, 2003, available at http://papers.ssrn.com/sol3/papers.cfm?abstract_id=452900 ; Oliver Budzinski, 'Monoculture versus diversity in competition economics', (2008) 32 Cambridge Journal of Economics 295. 
Austrian market process theory), Budzinski concludes from this pluralism that it is not possible to derive "an unequivocal, scientifically true antitrust policy" 61 . He is critical to the attempt to perform comparative evaluations of market performance in economies with different institutional and policy choices in order to decide which are the adequate competition policy programs (best practices), a procedure that is broadly used at the international level (OECD, ICN). These attempts underpin the idea that there is a superior, "objective", theory; however, as he immediately remarks, even within the Popperian framework, theories can be proved false but not true, therefore there cannot be any serious claim for an ultimate theory ${ }^{62}$. "Sustainable pluralism of competition theories" should thus serve as an imperative for science and public policy.

Budzinski's policy recommendations are nonetheless less clear. The main difficulty of his conceptualization lies with the different time frame and objectives of judicial decision-making, in comparison to those of the scientific process. For example, should the objective of theory pluralism lead the courts to choose a minority theory instead of a majority one, the two theories being equal from the point of view of explanatory power, for the simple reason that choosing a dominant theory will be reducing pluralism? On what practical basis should this choice for pluralism be made in this case? Would that require the artificial preservation of "degenerescent" research programs for the simple sake of pluralism? Budzinski's focus on pluralism (the end result to achieve) ignores an important aspect, which is mentioned in his study, the theory selection process. Any analysis of pluralism should depart from the consideration of the selection process and in particular the reasons that lead to its biased non pluralistic results, as demonstrated by the use of the terminology of "dominant" paradigm. It is certain that if the selection process, which can be conceived as applied practical reason, worked well, there would be no "dominant" theory, in the sense that the representatives of all "research programs" and "paradigms" will feel confident that their positions are equally taken into consideration in adjudicating each case.

The lack of trust in the selection process could be explained from the fact that there is the perception that actors ("research programs", "paradigms", "schools") behave strategically. The hypothesis examined in this study is that the existence of a market for economic experts may affect the scientific process of investigation in economics. Contrary to other disciplines, where forensic scientists and academic researchers form distinct scientific communities, the leading forensic competition economists are academics who actively participate in theoretical economic debates. Consequently, the emergence of a market for economic experts inevitably affects the research agenda of certain areas in economics (e.g. industrial organization) linked to competition policy. This introduces a novel research question, which has to be examined empirically, through the analysis of the work of economic consultancies, their links with academic economists, the emergence of a specialisation of forensic 
economists to defendant or plaintiff-friendly in order to enhance their employability, their links to lawyers and the judicial system, among others.

\section{Analyzing forensic economics from a sociological perspective: elements for a theory}

The theme under examination presents important theoretical challenges. We aim to study the emergence of forensic economists in competition litigation in order to evaluate their impact on the research agenda of industrial organization economics and to understand the evolution of this discipline. Our ultimate aim is to develop an understanding of how the production of scientific knowledge by economic consultancies affects the way economic knowledge originates and is processed as it becomes established, and ultimately, how this affects the éthos and values of the economic science produced. Hence, we will proceed with the aim

to examine forensic economics as an episode in the process of professionalization of economics by looking to the interrelationships between the various economics "professions" (academics, business and government economists),

(ii) to study the strategies of forensic economists developed in a specific field, where they interact (and compete) with other actors/agents,

(iii) to determine the influence of the professionalization process and, more specifically, the emergence of forensic competition economists, on the content and the structure of economic discourse. This third step will attempt to explore the links between the structure, institutional organization and the methodology/content of economics.

(iv) to explain how the economic knowledge originated from this new institutional setting affects the epistemological foundations of economic science and, more generally, the norms guiding good scientific research.

\subsection{The "professional project" of forensic economists}

The focus on the "professional project" of forensic competition economists should be perceived as a means of understanding the development of the occupation of providing economic advice in litigation to become a real "profession". Larson's conceptual framework might be helpful in understanding the process by which, forensic economists, as producers of special services, seek to constitute and control a market for their expertise ${ }^{63}$. Her approach breaks with the structuralist framework of Parsons $^{64}$. Larson highlights how the constitution of professional markets, a process

\footnotetext{
63 MS Larson, The Rise of Professionalism - A Sociological Analysis (University of California Press, 1977).

64 T. Parsons, Professions and Social Structure, in Essays in Sociological theory (Free Press: Glencoe, IL, 1954).
} 
that began in the nineteenth century, was an attempt to translate special knowledge and skills to social and economic monopolistic rewards.

The first phase of professionalization came through the constitution of professional associations and the subsequent closure of the domain through accreditation and professional examinations. This is certainly a strategy that characterizes the rise of the traditional professions in the $19^{\text {th }}$ century (law, medicine) but does not reflect the more sophisticated strategies adopted at the later stages of the development of the "professional project". Larson refers to the importance of developing a "cognitive basis" as a mechanism to control the providers of professional services in order to standardize and thus identify the commodity they provide $^{65}$. However, as she also remarks, "a cognitive basis of any kind had to be at least approximately defined before the rising modern professions could negotiate cognitive exclusiveness - that is, before they could convincingly establish a teaching monopoly on their specific tools and techniques, while claiming absolute superiority for them" ${ }^{\prime 66}$. The monopoly is thus constituted by the linkage of rewards with merit by means of formally universalistic criteria of recruitment and promotion and by the parallel construction of a "monopoly of credibility" with the larger public ${ }^{67}$. From this perspective, "cognitive standardization allows a measure of uniformity and homogeneity in the production of producers". Furthermore, "the more formalized the cognitive basis, the more the profession's language and knowledge appear to be connotation-free and objective" ${ }^{, 68}$.

It is argued that in economics, this process took the form of the "mathematizing inclination" 69 that provided the "internal logical consistency", through "methodological formalization" ${ }^{70}$, , but also the necessary closure of the discipline. As it is noted by Coats, "[...] the so-called mathematical-quantitative revolution in economics has brought the theoretical core of the subject much closer to the ideal of a "restricted" discipline"71. Larson's interactionist approach encourages the researcher to regard social processes as the product of individual and collective actions, and respectability as something which is actively pursued. The modern professional project tends to integrate the production of knowledge with professional practice. Professionalization becomes therefore a collective project which aims at market control. For this to occur successfully, we need to have on one side a specific body of knowledge, or expertise, including techniques and skills and, on the other, a market of services. Larson observes how

65 MS Larson, The Rise of Professionalism - A Sociological Analysis (University of California Press, 1977). at 15.

66 Ibid.

$67 \quad$ Ibid, p. 17.

68 Ibid. at 41

69 T. Lawson, 'The Nature of Heterodox Economics' (2006) 30 Cambridge Journal of Economics 483-505; G. Debreu, 'The Mathematization of Economic Theory' (1991) 81 American Economic Review 1-7.

70 R. E. Backhouse, 'If mathematics is informal, then perhaps we should accept that economics must be informal too' (1998) 108 The Economic Journal 1848-1858.

71 A.W.B. Coats, The Sociology and Professionalization of Economics (Routledge, 1993), p. 27 
"the notion of expertise incorporates contradictory principles (:) One the one hand, it embodies the rationalizing and universalistic legitimation of market monopoly, insofar as it is standardised expertise, accessible to all who care to be adequately trained and qualified. One the other hand, expertise is also used to claim superior rewards and to establish social distance from other occupational groups. ${ }^{72,}$

The establishment of corporations active in delivering professional advice constitutes another illustration of the "bureaucratic phenomenon" that "creates the structural context of successful professionalization",73, which is another means to enhance the reputation of a profession and the constitution of professional markets. The focus on the constitution of professional markets leads to comparing different professions in terms of the marketability of their specific cognitive resources.

One could consider the applicability of this framework to the professionalization of economics with the emergence of the "profession" of forensic economists, as a step in the professional project of economics. In a series of studies, Coats focuses on the transformation of economics from an academic subject and occupation to a professional venture, but also on the interaction between the professional project of economics and the evolution of the professional identity of economists ${ }^{74}$. According to Coats, "(i)n the economics community the academic ideal, namely that of the pure research truth-seeker, the detached non-partisan expert, outweighs any more pragmatic conception of professionalism or public service" 75 . He argues that "the conception of professional neutrality [...] has exercised a potent force in the creation and maintenance of the economists' collective professional identity"76.

An illustration of this evolution is how the Keynesian revolution of the late 1930s and 1940s led to an explosion of non-academic, essentially government jobs, in the area of economics. The academic tradition of neutrality, but also the focus of government technocracy on public service might have contributed to the emergence of a culture of impartial expertise in the collective professional identity of economists. This has been so strongly geared towards efficiency and free markets that economists questioned more openly and more persistently than other social scientists the merits of professionalism and consequently the quest for monopoly ${ }^{77}$. According to Coase, "although academic economists necessarily influence entry into the profession through their control of the degree process, they have consistently opposed any kind of formal professional accreditation" ${ }^{, 78}$. This characteristic establishes an important distinction between economists as a "newer profession" and more historic professions, such as medicine and law. Again, according to Coats,

\footnotetext{
72 MS Larson, The Rise of Professionalism, above, p. 136.

73 Ibid., at 145 .

74 See, the collection of essays, A.W. Coats, The Sociology and Professionalization of Economics (Routledge, 1993).

75 Ibid., p. 398.

76 Ibid

77 On the attitudes of economists on monopolies see, G. Stigler, The Economist as a Preacher (Blackwell: Oxford, 1982), 38-54.

78 A.W. Coats, The Sociology and Professionalization of Economics, op.cit., at 399.
} 
“(u)nlike the older type of so-called 'status' professions such as law or medicine, whose practitioners exercise considerable control over membership and occupational conditions, the newer type of profession remains closer to the academic conditions of proof... gives less protection to the individual member ... and concerns itself less with official certificates of competence than the traditional profession. Its members' organizations are "learned societies" and their allegiance is primary to the substantive field, not the guild. Although their functions may be performed largely in a bureaucratic context, the science, not the bureaucracy, defines employment standards and because the work is largely science, not art, it can be evaluated with some precision"79. This statement should nevertheless be revised in view of the emergence of forensic economics as an important occupation for economists specialised in Industrial organization. One could indeed need to look to statistics on the percentage of economists following a career in the private sector, as opposed to economists active in academia and the government to measure the impact of forensic economics on the formation of the economists' collective identity ${ }^{80}$. It is clear that forensic economists have resisted so far to some form of accreditation or professional examination that would control their emergent professional market. Is this a strategy that aims to reinforce the respectability and high status of the profession? Can the emergence of forensic economics lead to a redefinition of the collective identity of economists towards a position of relative (and not absolute) adversity to monopoly and consequently make them more inclined to pursue some form of legal monopoly of knowledge-based services? This is an important question to be explored.

Yet, the focus on the monopoly quest of the "professional project" of economics might be reductive. As Abbott highlights, to study professionalism is misleading as it looks to form rather than content, and largely ignores that "a fundamental fact of professional life is inter-professional competition [...] (i)t is the history of jurisdictional disputes that is the real, the determining history of professions" ${ }^{\prime \prime 1}$. Others highlight the importance of the relations between the professions and the State as part of the aims of the "professional project". Burrage focuses specifically on the legal profession; he notes that "if all professions in their pursuit of monopoly and privilege have entered into a special relation with the State, lawyers in all parts of the division of legal labour had a specific relationship to an arm of the State - judicature - and in some cases were unambiguously integrated into the State apparatus" ${ }^{\prime 2}$. A similar strategy may be identified with regard to economists.

\footnotetext{
$79 \quad$ Ibid., p. 420.

80 There are a number of statistical studies available. See, http://www.aeaweb.org/gradstudents/JobMkt_Salary_Issues.php More general surveys of economists' beliefs include D. Colander, The Making of an Economist - Redux (Princeton University Press, 2007); D. Colander, The Making of a European Economist (Edward Elgar, 2009).

81 A.D. Abbott, The System of the Professions: an Essay on the Division of Expert Labor (University of Chicago Press, 1988), at 2.

82 M. Burrage, Revolution and the Collective action of the French, American and English legal professions, 13(2) Law and Social Enquiry: The Journal of the American Bar Foundation 1988, 225 277 , at 238 .
} 
The expansion of the economic profession to the regulatory agencies' arena in the area of competition law and utilities regulation has led to a multiplication of job opportunities in the private sector of the economy and the rise of economic consultancies. The institutionalisation of roles, such as that of chief economist in various competition authorities worldwide illustrates this strategy of entanglement of the State power by economists. The next frontier seems to be the judiciary, with the recent calls for more specialised jurisdictions disposing of some form of economic expertise $^{83}$.

The monopolization of this emergent professional market should not be considered as the only objective sought; the promotion of the value of efficiency, dear to the collective professional identity of economists, could also constitute an important aim. In this vein, Halliday notes that the legal profession has a distinctive relation with the State because of its interest for an effective legal system, the legitimacy of law as an institution and the intrinsic merits of procedural justice and legalism ${ }^{84}$. Some other authors highlight the positive implications of professionalism as a form of social organization: professionalism is perceived as an ideal type grounded in the political economy and presents the concept as a third logic, or a more viable alternative to consumerism and bureaucracy. It refers to a world where workers with specialized knowledge and the ability to provide society with especially important services can organize and control their own work, without directives from management or the influence of free markets. Widespread attacks by neoclassical economists advocating efficiency are challenging the social value of credentialism and monopolies ${ }^{85}$.

In her more recent work, Larson has focused on the relations between knowledge and power by employing the terminology of "discipline", rather than the narrower concept of "profession"86. Larson and other authors, such as Goldstein ${ }^{87}$, highlight the ambiguous duality of the concept of "discipline", perceived on one side as "the maintenance of a set of rules" and on the other side as a "branch of knowledge". The monopolization of a specific discourse constitutes the means through which power is exercised. This discursive monopoly is granted if the profession, transformed to a discipline, succeeds in presenting its theoretical apparatus as scientific, that is, empirical, objective, disinterested and methodologically rigorous ${ }^{88}$. Larson notes that the University departments constitute the core regions where professional discourse develops ${ }^{89}$. The links between the communities of academic economists and forensic

\footnotetext{
83 On specialised jurisdictions see, L. Baum, Specializing the Courts (University of Chicago Press, 2011).

$84 \quad$ T.C. Halliday, Beyond Monopoly (1987)

85 E. Freidson, Professionalism: The Third Logic (University of Chicago Press, 2001).

86 M.S. Larson, "In the Matter of Experts and Professioinals, or How Impossible is to Leave Nothing Unsaid", in M Burrage and R. Torstendahl (eds.), The Formation of the Professions, (SAGE, 1990), pp. 24-50, p. 37.

87 J. Goldstein, "Foucault among the Sociologists: The Disciplines and the History of the Professions", 23 History and Theory 170-192 (1984)

$88 \quad$ According to the Mertonian conception of science.

89 M.S. Larson, "In the Matter of Experts and Professionals, or How Impossible is to Leave Nothing Unsaid”, above, pp. 37-38.
} 
economists in the area of Industrial Organization and forensic competition economics guarantee the semblance of neutrality of the produced knowledge, conceived as a strategy for exercising power. But what is the social space on which interactions, transactions and eventually the power is exercised?

Focusing on the relations between academic and forensic economists and on the evolution of their professional project ignores the entanglement of economics with other "disciplines" and "professions" with which they are in constant interaction, as well as the interest of universalizing power struggles, the literature until now focusing on the national level. The work of Dezalay highlights how the emergence of a new international arena of expertise blurs the boundaries between the different professions by enabling mainly national actors to adopt international strategies that will build their power at home ${ }^{90}$. Dezalay narrates the basic shift that took place in Latin America in the 1980s and 1990s from a legal-centered approach oriented towards the European continent to an economics-based approach oriented to the United States. The economists employed "cosmopolitan scholarly strategies" leading to the hybridization of business law by subsequent law reforms according to the dictates of economists. One could add the links that exist between the corporatisation of forensic economics and the emergence of large multinational law firms, as a further illustration of this international dimension.

What these strategies show is that the concept of profession, with its welldefined boundaries, is a "prefabricated concept" that ignores the "process of constitution of specific world fields, into which the national fields have been drawn, while retaining a greater or lesser relative autonomy" "91. I will attempt to sketch how the concept of "Field" might provide a better starting point in understanding these complex interactions.

\subsection{Forensic economics and their "Field": towards a linkages approach}

The conceptual apparatus offered by Bourdieu's theory of practice enables us to map and understand the relation between forensic economists and other actors with whom they interact in the social space, but also to explore linkages with the sociology of knowledge literature ${ }^{92}$.

For Bourdieu, practice results from the relation between one's dispositions (habitus) and one's position in a field (capital) within the current state of play of that social arena (field)

Practice $=($ habitus $)($ capital $)+$ field

$90 \quad$ Y. Dezalay \& D. Sugarman, Professional Competition and Professional Power (Routledge, 1995); Y. Dezalay \& B. G. Garth, The Internationalization of Palace Wars (University of Chicago Press, 2002).

${ }_{91}$ P. Bourdieu, Foreword, in Y. Dezalay \& D. Sugarman, Professional Competition and Professional Power (Routledge, 1995);

92 P. Bourdieu, Outline of a Theory of Practice (Cambridge University Press, 1977). 
Each social field of practice can be understood as a competitive game or a field of struggles in which social agents strategically interact in the quest to maximise their positions. Habitus consists in a structure comprising a system of dispositions which generate perceptions. It denotes a relation of knowledge or cognitive construction that contributes to the constitution of the field ${ }^{93}$. The social field consists of positions occupied by social agents. At stake in the field is the accumulation of capital, which can take four forms: economic (e.g. money, assets), cultural (e.g. knowledge), social (e.g. networks, affiliation) and symbolic (e.g. credentials). Employing field theory, our research should attempt to analyse the positions of the field vis-a-vis the field of power and to map out the objective structures of relations between the positions occupied by the social agents or institutions who compete for the legitimate forms of specific authority.

It is possible to conceive the social arena of competition law litigation as a specific field on which different players, forensic economists, lawyers, academic economists, regulators, judges develop strategies. Each of these groups detains a position in the field that is determined by their specific disciplinary competences. Each of them competes with each other for the acquisition of symbolic, and then economic and social capital. Yet, despite their different dispositions and strategies, these actors should be conceived as being entangled in a mutual process of influence that contributes to the ongoing co-construction of a field.

It follows that focusing the analysis on the emergence of the profession of forensic economists without examining the complex relations forensic IO economists develop with other actors they interact with, profoundly misunderstands their strategies and misses the important changes that take place in their dispositions, their specific doxa, when internalizing the specific economic and social conditions that characterize the field.

One could aim to map the positions of the different actors and their relation to the field of power, in our case the government regulatory bodies and the judiciary. The integration of scientific knowledge in the regulatory decision-making process has been a major source of legitimation of technocracy. Jasanoff noted how the expansion of the role of technical experts with the constitution of specific regulatory institutions led to an isolation of the scientific and political decision-making and the positivistic value-fact separation". It has also led to the emergence of a "regulatory science (science used in policy making)" or "mandated science", which presents distinct characteristics from "science in a research setting" (or ordinary science) ${ }^{95}$. Regulatory science includes "a component of knowledge production", as does ordinary science, but also a "substantial component of knowledge synthesis", which includes

\footnotetext{
93 P. Bourdieu \& L. Wacquant, An Invitation to Reflexive Sociology, vol. 1 (Polity Press: Cambridge, 1992), pp. 127.

$94 \quad$ S. Jasanoff, The Fifth Brand - Science Advisers as Policy Makers (Harvard University Press, 1990), p. 17.

${ }_{95}$ On the expression "mandated science", see Liora Salter, Mandated Science (Dordrecht, Netherlands, Kluwer, 1988).
} 
"secondary activities, such as evaluation, screening, and meta-analysis" 96 . "Regulatory science" is largely "predictive", as it feeds decision-making, the later being constrained by time and resources, in contrast to an ordinary science-setting where a long process of peer reviewing assures a gate-keeping function. As Jasanoff explains, "science carried out in non-academic setting may be subordinated to institutional pressures that critically influence researcher's attitudes to issues of proof and evidence" and "in turn affect the packaging and presentation of scientific results" $"$. An important difference between pure and mandated science, in our case academic economics and forensic economics, resides in the definition of standards by which each is evaluated. Jasanoff rightly notes that

"(a)cademic research, on the whole, works within established scientific paradigms, subject to relatively well-negotiated prior understandings about what constitutes good research methodology [...] Instead, the guidelines for validating science in the regulatory context tend to be fluid, controversial and arguably more politically motivated than those applicable to university-based research" 98 .

In essence, the contention is that forensic economics is shattered between two different conceptions of true beliefs: what is taken as true and false in court is sometimes different from what might be taken to be scientifically true or false. This turns us to the next question, which is the influence of forensic economics (the discourse produced by forensic economists) on the content and the structure of economic thought.

\subsection{The influence of forensic economists on the content and the structure of economic thought}

The recourse to the "regulatory science" of economics as a source of wisdom for competition law can be merely explained by the quest of the antitrust technocracy $^{99}$ for credibility and thus ultimately authority. The perception of the "regulatory science" of economics as a significant hermeneutic tool in the enforcement of competition law mirrors the image of the ordinary science of economics as a quintessentially objective quest for knowledge. It is because the "regulatory science" of economics emulates or approximates the "mores" of the ordinary scientific process that it becomes a valuable source of authority. The underlying assumption is that the credibility of such knowledge rests on objective and impartial epistemic achievements. Thus, being more than a simple moral or technical prescription, the image of objectivity operates a legitimacy function, as a rationale for the exercise of power. The delinking of "regulatory science" from its social context

\footnotetext{
$96 \quad$ Ibid., p. 77.

97 S. Jasanoff, The Fifth Brand - Science Advisers as Policy Makers (Harvard University Press, 1990), p. 78

$98 \quad$ Ibid., p. 79.

99 D. Crane, Technocracy and Antitrust. Cardozo Legal Studies Research Paper No. 208; Texas
} Law Review, Vol. 86, 2008. Available at SSRN: http://ssrn.com/abstract=1030632 
and its consequent linkage to the conventional imaginary of "ordinary science" participates to this effort of promoting its credibility as a hermeneutic tool. This indirect reference to the éthos of "ordinary" science has resolutely a Mertonian taste. The assumption is that the "regulatory science" of economics will fulfil the four sets of institutional imperatives set by Merton: universalism with its requirement of objectivity and impartiality, communism with its aversion to secrecy, disinterestedness with its emphasis on competition and testability, and organized scepticism with its opposition to crystallization ${ }^{100}$. One could identify in the efforts of "regulatory science" to integrate peer review processes and a strict scrutiny by experts of the verifiability of results, an attempt to emulate the institutional imperatives of "ordinary" or "academic science"101.

The Mertonian conception of disinterestedness advocates a primordial distinction between the éthos of the scientist and the professional éthos:

"The scientist does not stand vis-á-vis a lay clientele in the same fashion as do the physician and lawyer for example. The possibility of exploiting the credulity, ignorance and dependence of the layman is thus considerably reduced $[\ldots]^{\prime 102}$.

In the Mertonian conception of science, rewards for scientists are "largely honorific, since even today, when science is largely professionalized, the pursuit of science is culturally defined as being primarily a disinterested search for truth and only secondarily a means of earning a livelihood" 103 . Merton went even further by warning that " $(\mathrm{t}) \mathrm{O}$ the extent that the scientist layman relation does become paramount, there develop incentives for evading the mores of science" ${ }^{\text {"104 }}$.

The association of the scientific process with other segments of the social structure could be a source of predicament and tension. Writing in 1938, Merton identified the problem of the domination of the scientific enterprise by political authorities, in view of the expansion of the role of the State, and the risks that this paused to the norms of the scientific éthos:

"The norms of the scientific éthos must be sacrificed insofar as they demand a repudiation of the politically imposed criteria of scientific validity or of scientific worth. The expansion of political control thus introduces conflicting loyalties $[\ldots]$

The sentiments embodied in the éthos of science - characterized by such terms as intellectual honesty, integrity, organized scepticism, disinterestedness,

\footnotetext{
100 R.K. Merton, The éthos of Science (1942), in R.K. Merton, On Social Structure and Science (University of Chicago Press, 1996), pp. 267-285.

101 S. Jasanoff, The Fifth Brand - Science Advisers as Policy Makers (Harvard University Press, 1990). On the importance of peer review in science see, R.K. Merton, The Reward System of Science (1957), in R.K. Merton, On Social Structure and Science (University of Chicago Press, 1996), p. 296.

102 R.K. Merton, The éthos of Science (1942), above, p. 275.

103 R.K. Merton, The Reward System of Science (1957), above, pp. 303-304.

104 R.K. Merton, The éthos of Science (1942), above, p. 275.
} 
impersonality - are outraged by the set of new sentiments that the State would impose in the sphere of scientific research "105.

The intervention of an external authority, outside the realm of the process of scientific discovery, is, thus, seen as a major anomaly to the Mertonian framework of impartial science.

Turning to the research question examined in this study, it is clear that the emergence of forensic economics challenges this core conception of science. Acting as party experts in a regulatory or a litigation setting, forensic economists are inevitably influenced by their material interests in the dispute, notwithstanding the effort of the legal system to establish a duty of the expert to the (impartial) court ${ }^{106}$. The substantive findings of the expert economist are not always made public, as this might jeopardize the likelihood of success of the case, if these findings are adverse to the interests of their clients. This feature contradicts the requirement of communism, secrecy being the antithesis of this norm. The payment of hefty fees to economic experts by the litigants negates also the essence of the norm of disinterestedness. Merton's concern over the influence of the external authority on the definition of norms of scientific validity seems to describe well the situation of forensic economics, with the (important) difference that it is the market for economic advice that interacts with the scientific process, and not the political authorities or the State in general, as was feared by Merton. Certainly, this focus on the State is historically contingent: State intervention was predominant in the late 1930s, when Merton was publishing his Science and the Social order, while our time period is marked by the global expansion of markets. Nevertheless, legal requirements of admissibility of economic evidence and the substantive evaluation of economic theories with the mechanism of peer review and/or various legal standards of proof reproduce the Mertonian framework. The legal system appears permeated with this conception of scientific purity and the dissociation of science from various social interests.

This study resolutely opposes this view. We start from the hypothesis that every knowledge created to serve policy needs, in this occurrence the "regulatory science" of forensic economics, is sociologically distinct from other forms of knowledge and in particular its academic/ "ordinary science" counterpart. Regulatory science is actively developed in response to practical contingencies and produced by social groups engaged in particular activities. Knowledge is thus socially determined. Mannheim refers to these extra-theoretical factors that are not driven by the "inner dialectic" of the thought ${ }^{107}$. We should aim precisely to examine these "existential factors" influencing the content of economic knowledge in the area of Industrial Organization. One can assume that the conditions of the existence of an idea, its historical and social genesis, exercise an inevitable influence on its content and form. Every assertion can thus only be relationally formulated: an assertion by an economist

105 R.K. Merton, Science and the Social order (1938), in On Social Structure and Science (University of Chicago Press, 1996), p. 280.

$106 \quad$ According to Part 33.2 of the UK Civil Procedure Act.

107 K. Mannheim, Ideology and Utopia - Introduction to the Sociology of Knowledge (Harcourt, Brace \& Company, 1949), 
in the context of a trial or regulatory decision-making should be assessed differently than her assertion in the context of a purely academic discussion. It is thus important to make an effort of "sociological imputation", in order to explain the impulse and the direction of development of economic thought in each of these contexts, by looking to the composition of the groups which express themselves in that mode of thought ${ }^{108}$.

This effort can take two forms, according to Mannheim:

"In the first place it is a purely empirical investigation through description and structural analysis of the ways in which social relationships, in fact, influence thought.

This may pass, in the second place, into an epistemological inquiry concerned with the bearing of this interrelationship upon the problem of validity" 109 .

With regard to the first step of the inquiry, taking an interactionist and constructivist perspective on scientific knowledge, the "Strong programme" in the sociology of knowledge may help us to highlight and understand the "social component ${ }^{110}$ " of the knowledge produced by forensic economists. For Bloor, "(d)eductive logic is the creature of our inductive propensities" and "the product of interpretative afterthoughts" ${ }^{\prime 11}$. Informal negotiations, what is otherwise referred to as "an interpretative or hermeneutic process", ${ }^{112}$ over general propositions constitute the core of the process of knowledge production" ${ }^{113}$; "Negotiations create meanings" Adopting a form of methodological and cognitive relativism, the proponents of the strong programme argue that "ideas of knowledge are based on social images" and that "objectivity is a social phenomenon" ". Social interests, in particular "vested professional interests", influence the standards and conventions of science ${ }^{116}$. However, the fact that the social component is always present does not necessarily mean that it is the only component that triggers change. How then to distinguish the "social component" of academic economics from that of forensic economics?

This study assumes that the content of scientific knowledge is shaped in a complex social process. Social networks and relations of power have important implications on the directions of the future research agenda and on the emergence of dominant schools of thought in economics. For example, legal mechanisms, such as specific standards for the admissibility and evaluation of expertise, may be used by the different actors of the system in order to gain a leading position for their "school" of economic theory. The social costs include the costs flowing from the monopoly of a particular school of economics in the marketplace of ideas. This is a significant concern, in view of the important economic consequences of competition law

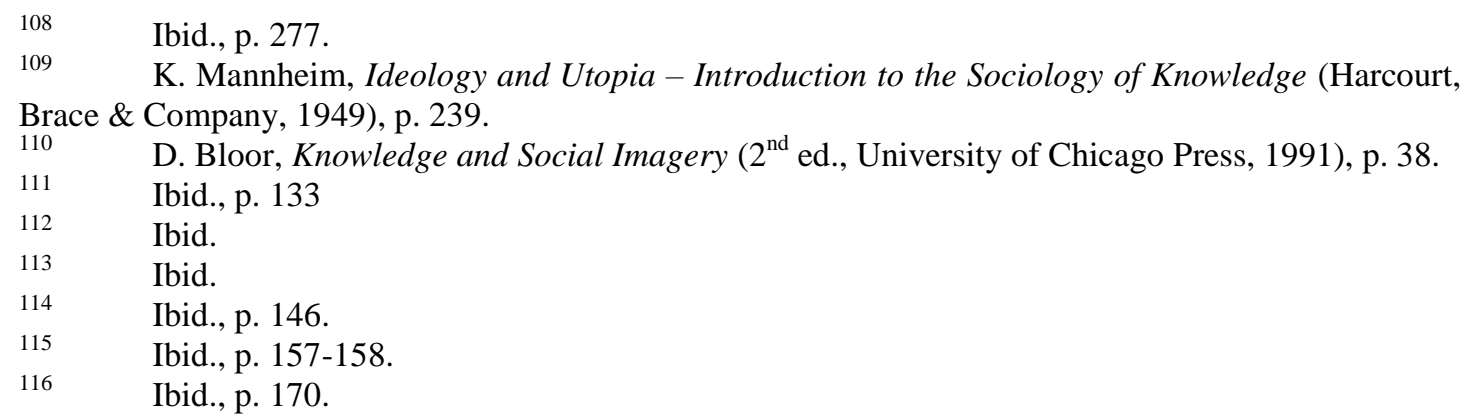


litigation and the benefits of scientific pluralism, the existence of different research programs, for the consideration of all important aspects of human behaviour, not necessarily taken into account by all schools (an example could be the concept of bounded rationality).

Competition law may be an important and valuable "ally" for competing networks, in particular because of the professionalization of economic expertise in this sector and the ability to attract new members to join the "schools" or "network", essentially because of the important "rents" to be shared. The assumption is that, as any other rational economic agent, economists are rational maximizers of wealth engaged in rent-seeing activities ${ }^{117}$. One could conceptualize the members of an economic "school" or network as seeking to increase the relevance of their "school" of thought for legal analysis and exclude competing networks.

Proving the blurring of the distinction between academic economists, motivated by the reward process of open science, and forensic economists, motivated by a different reward market-based process, is an important step in recognizing that radical changes in the reward structure of science leads to a biased selection process in terms of theory pluralism. The blurring of the distinction between forensic economics and academic economics corresponds to actual practice: exchanges between expert witnesses are not confined to the courtroom but, in practice, extend to the broader academic debate, in journals, conferences, the SSRN etc. Preparing the public defence of a specific theory and position that is favourable to one of the parties in these academic circles is part of the strategy to establish the legitimacy and persuasiveness of the claim. Ironically, this is also one of the side-effects of the distrust of judges towards expert witnesses. When they refer to economic reasoning, judges tend to grant more weight to published economic commentary rather than to the expert witnesses' reports.

Drawing on Actor Network Theory, Yval Yonay examined the conflict between the old institutionalists and neoclassical economists in the Inter-War era ${ }^{118}$. The struggle between these two "networks" is of particular importance for my purposes, as each school has profoundly influenced competition law and policy in different periods of time. Institutionalists were attached to the empirical and inductive model of science. For them valid theory should be dynamic, evolutionary and relative, concerned broadly and objectively with processes rather than with precise implications of conceptual definitions, scientifically inductive rather than formalistically logical in method. ${ }^{119}$ Neoclassicists counter-attacked by pointing out to those aspects of prestigious sciences that were more similar to the deductive methods of neoclassical economics, such as theoretical physics. In the absence of the

117 See, Jesus P. Zamora Bonilla, "Economists: truth-seekers or rent-seekers?", in Uskali Mäki (ed.), Fact and Fiction in Economics CUP, 2002), at 356.

118 Yuval P. Yonay, The Struggle over the Soul of Economics, Institutionalist and Neoclassical Economists in America between the Wars (Princeton University Press, 1998), at Chapters 4-7.

119 Geoffrey M. Hodgson The Evolution of Institutional economics, (Routledge, 2004); Tony

Lawson, "The Nature of Institutional Economics", (2005) 2(1) Evolutionary and Institutional Economics Rev 7. 
possibility of laboratory experimentation (as neoclassical economists rejected introspection as a valid method of observation), economics was justified in being even more deductive in its nature than physics. Institutionalists' emphasis on the role of social institutions is a further source of disagreement. In contrast, neoclassical economists focused on a specific aspect of human volition and insisted that economics should focus on illuminating the rational aspect of human behavior, without integrating in the analysis exogenous factors, such as institutions. The trial of strength between institutionalists and neo-classical economists was finally won by the latter, because of the alliance of neoclassical economic theory with mathematical economics, in particular during the 1950s. ${ }^{120}$ The power of attraction of mathematical economics was augmented by the development of econometrics as a new approach to quantitative research that differed from the way institutionalists practiced such research. The alliance between neoclassical economics, mathematical economics and econometrics managed to turn quantitative research from an ally of institutionalists into an ally of neoclassical economics. The intense use of the language of mathematics or mathematical reasoning has indeed been considered by some authors as the demarcation point between orthodox (neoclassical) and heterodox economics. $^{121}$

As different networks engage in continuous trials of strength, one cannot exclude that the legal system may operate as an important strategic ally. The normative force of the legal system will ensure that the societal structure that a social science, such as economics, attempts to explain, will be profoundly influenced by the concepts and way of thinking of the mainstream economic theory of the moment. It is quite well accepted and documented that economic theory may be the conceptual substratum of many parts of the legal system. One may give the example of the laissez-faire doctrine of the classical school of economics as a main inspiration of the Western legal system until the emergence of the progressive movement in late $19^{\text {th }}$ century. Soviet Union, where the entire legal system was built on the foundations of Marxism also provides a compelling example. It seems that the integration of economic learning by the legal system constitutes an assurance of success in the trials of strength that oppose different networks in economics and has stabilizing effects for the mainstream. It may also explain the considerable lag between the emergence of a new theory/network as mainstream in science and its adoption by the legal system. For example, although the Chicago school criticism to activist antitrust enforcement dates from the late 1950s/1960s, their influence at the courtroom has been felt much later (at the end of 1970s). The particular characteristics of legal authority and precedent may explain lawyer's reticence to embrace new economic theories.

It could be argued that one of the strategies of scientific "networks" is to influence, to take up the legal system. The legal system will bestow its authority on the theories defended by the members of the network. In other words, the legal system

\footnotetext{
$120 \quad$ Yuval P. Yonay, The Struggle over the Soul of Economics, at 187-190.

121 Tony Lawson, 'The Nature of Heterodox Economics', (2006) 30 Cambridge Journal of Economics 483, 488-490.
} 
is a powerful ally. This point of view has important implications on the debate over scientific economic expertise in courts. The exclusion or marginalization of competing networks from the process of expertise, by presenting them as unscientific or unreliable, constitutes a rational strategy. This may be particularly attenuated by the development of an exclusionary éthos for certain types of economic expertise, based on methodological concerns, themselves influences by methodological monoculture.

The legal system may be an important and valuable "ally" for competing networks, in particular because of the professionalization of economic expertise in this sector and the ability to attract new members to join the "schools" or "network", essentially because of the important "rents" to be shared. The assumption is that, as any other rational economic agent, economists are rational maximizers of wealth engaged in rent-seeking activities ${ }^{122}$.

There has already been some work on the interaction between the social context of the production of economic knowledge and the content of economic thought. George Stigler has performed a statistical analysis of the communications network, career patterns, reward system and social stratification of economics, through the study of the content and the status of economic journals ${ }^{123}$. Stigler noted the importance of economist's influence in policy, in particular by examining the integration of economists at the Federal Trade Commission and their interaction with lawyers at the agency ${ }^{124}$, as well as by the type of employers of doctorates in economics, business and government representing a quarter of the Doctorates' employers in $1969^{125}$. Stigler observed that before the establishment of independent commissions and boards regulating the industry the detachment of economists from "contemporary policy was Olympian"126. Nevertheless, under the influence of the German Historical school and the institutionalist movement in the early quarter of the $20^{\text {th }}$ century, American economists have been increasingly involved in matters of policy. Stigler documented the large number of publications on monopoly and public regulation as appearing at the Index of Economic Journals from 1900 to 1965 and noted that during the first decade of the $20^{\text {th }}$ century, the number of articles published on the problem of monopoly was substantially higher than their number during 19601965, an era marked by an intensive antitrust enforcement in the United States. These findings do not challenge the main contention of this research, which is that the rising professional interest of economists in the area of competition law and economics led to an increase of the interest of academic articles published on these topics. Indeed, it is in the mid to late 1970s that the US Supreme Court and the antitrust agencies began having access systematically to economic inputs in their decision-making practice.

122 See, Jesus P. Zamora Bonilla, 'Economists: truth-seekers or rent-seekers?', in Uskali Mäki (ed.), Fact and Fiction in Economics CUP, 2002), at 356.

$123 \quad$ George Stigler, The Economist as a Preacher (Blackwell, Oxford, 1982).

124 Ibid, Chapter 4, The Economists and the Problem of Monopoly.

125 Ibid., p. 195

$126 \quad$ Ibid., p. 129. 
Coats examined also the significance of the professionalization process of economics $^{127}$. He specifically focused on the interrelationships between the various economics professions (academic, government economists, business). Drawing on the Strong Programme in Sociology of Scientific knowledge ${ }^{128}$, Coats highlights the importance of the social context of scientific thought for the formation of beliefs and scientific concepts. Conventions approved by the scientific community form the essence of all scientific concepts, theories, tests and judgements. Reference to specific, local, contingent circumstances is thus an important element of understanding the emergence of a scientific concept, as each scientific community has its own accepted patterns of concept application. Coats analyses the resistance of economists to the adoption of a sociological interpretation of their discipline and the embracement of the quantitative logic in economics, as forming part of the strategy of economists to bring their subject matter closer to the "ideal of a restricted discipline" and to enhance the intellectual authority and autonomy of economics by excluding politically sensitive questions from the scope of the discipline ${ }^{129}$. Hence, there are links between the methodology and scope of economics and the trend towards their professionalization. For Coats, "the rise of professionalism both within the academic community and in society at large represented an effort by new specialist groups to gain social status and market power" ${ }^{\prime 30}$. This took first place in the academic field, the first associations of economists aiming to transform their subject to an autonomous, from moral philosophy, academic discipline. Coats narrates the "academization" of economics, "meaning that the university became the principal intellectual and social context for the advancement of scientific economics" in the late $19^{\text {th }}$ century ${ }^{131}$. However, he also notes that the rapid growth of non-academic opportunities, in particular in government, following the Great Depression and the rise of state interventionism in the 1930s, challenged the traditional academic locus of scientific economics. Coats alludes to the inevitable influence this had on the content of economic thought, although this part of the argument has not been further exploited in his analysis. Nevertheless, the problem is set in quite unambiguous terms:

"[...] in so far as academic and non-academic employers and employees attach markedly different values to specific components in the economist's knowledge and skills, the scope for dominance by a reputational elite is correspondingly undetermined"132.

If the "academization" movement in economics led to the abandon of certain contentious questions, such as wealth distribution and distributive justice, from the economists' areas of interest, and the narrowing down of scientific economics, the second professionalization phase, with the development of careers in government and

A.W.B. Coats, The Sociology and Professionalization of Economics (Routledge, 1993).

D. Bloor, Knowledge and Social Imagery (Routledge \& Kegan Paul, 1976).

A.W.B. Coats, The Sociology and Professionalization of Economics (Routledge, 1993), p. 38.

Ibid., p. 138.

Ibid., p. 40.

Ibid., p. 41-42. 
business, might also generate a different intellectual trend in economics and possibly lead to changes in the internal values and hierarchy of economic thought.

Coats does not examine this angle, but instead links the "professional ideology" of economists to the conception that they constitute "neutral objective" experts. In the economics community, "the academic ideal namely that of the pure research truth-seeker, the detached non-partisan expert, outweighs any more pragmatic conception of professionalism or public service" ${ }^{\prime 133}$. The conception of "professional neutrality" has exercised "a potent force in the creation and maintenance of the economist's collective professional identity"134. Coats highlights how the emergence of agricultural economics as a distinct field of scientific economics is intrinsically linked to the increasing role of economists in some areas of government. Yet, Coats' analysis, although useful from a descriptive point of view remains incomplete. First, he does not explain how this movement of professionalization outside academia affected the content of economic thought produced, its methodology and its standards of validity. Second, his choice of studying the role of economists' in government offers limited opportunities to identify the differences that might exist between the content of the knowledge produced in academia and in government. Economists working in government are motivated by the pursuit of public interest objectives, the nature of the interests of their employer, the government, being by essence compatible with the image of the economist as a non-partisan expert. Coats thus misses the inherent tensions between the role of the economist as employee and his self-framed imaginary of neutral expertise, which would have been more visible, had he focused instead on the examination of the role of economists in business, and in particular, as opposing experts in litigation and regulation.

Davies' work suffers from a similar narrowness of perspective ${ }^{135}$. Noting the increasing role of the economic logic in government decision-making, and the subsequent integration of economists in public bureaucracies, in particular in the field of competition law, Davies attempts to understand the normative presuppositions of government economists, as opposed to their academic peers. He observes that the antitrust economist has to strike "uneasy bargains" with lawyers and that "the scientific authority of neo-classical analysis must be balanced against the political, bureaucratic authority of the lawyers within the anti-trust agency"136. We are on familiar ground here, the content of "regulatory economics" being somewhat different from that of "academic economics". Taking a Weberian approach and employing semi-structured interviews with two dozens of government economists working for the European and the US competition agencies, Davies examines the inward and external vocations of antitrust economists. He notes that antitrust government economists are intensively engaged with academic groups in their discipline and seek

\footnotetext{
133 Ibid., p. 398.

134 Ibid.

135 W. Davies, Economic advice as a vocation: symbioses of scientific and political authority,

(2011) 62(2) The British Journal of Sociology, pp. 304-323.

$136 \quad$ Ibid., p. 306.
} 
publicity and transparency on their work, through academic publications, which is unusual for bureaucrats. There exist also important differences as to the normative presuppositions of each group: bureaucratic economists carry more (neo-classical theory) presuppositions and exclude more questions of worth than academic economists; the empirical mind-set seems also more entrenched with bureaucratic economists. What transpires from Davies' work is that the "overlap between the scientific and the bureaucratic political vocation" of antitrust bureaucratic economists "leads to an intensification of certain norms and rituals" "137. Yet, Davies misses an important dimension of the story by not examining how the emergence of forensic economists, working as party-experts in litigation, might affect this transformation of norms and rituals. He also neglects to study thoroughly the interaction between lawyers and economists in antitrust decision-making, by exploring specific case studies where the standards of validity of neo-classical price theory analysis had to adjust to the legal requirements of proof or, more generally, the principle of legal certainty.

While not focusing on the competition economics' field, Marion Fourcade's excellent comparative cultural sociology analysis of the dialectic relationship between culture and economics in United States, France and the UK provides a useful account of the linkages between the ideals of the profession of economists and the transformation of the content of economic analysis ${ }^{138}$. Fourcade reflects on the impact of national constellations and various institutional logics on the development of economic theory and methodology. Her case study consists in the rise of "the economic industry", with the contracting out by government of many decisionpreparation tasks to economists, either integrated in the government bureaucracy or in the academic field. Although she notes the increasing entanglement of economics with the corporate world and more generally the marketplace, as well as the emergence of a substantial market for economic consultants in the legal sector, this is not part of her main narrative. The process of "marketization of economics" is clearly noted, but its implications for the evolution of economic thought rest unexplored. A possible reason might be that her comparative perspective limits the scope of her study to the interaction of economists and government, as the role of economists in the private sector is more limited in France and the UK, than it is in the United States, or at least it forms a very recent occurrence. Nevertheless, her observations on the "scientific professionalism" of economics, as a result of the intervention of economists in public and private arenas, and the fact that the relationship between economic knowledge and state power define in large part the field's social purposes and the distinctive identity of its practitioners, provide a fruitful perspective of particular interest for the purposes of our study on forensic economics. Yet, Fourcade's emphasis on the government sphere only, omits from her analysis the emergence of a global market for economic advice and the transformation of economists to "merchant professionals", evolution that she confines to the specific

$137 \quad$ Ibid., p. 319

138 M. Fourcade, Economists and Societies (Princeton University Press, 2009). 
institutional and cultural context of the United States ${ }^{139}$. Yet, the area of competition law illustrates a profound transformation of economic practice in the areas of Industrial Organization and microeconomics, not only in the United States, but also in all the major European jurisdictions, where economists have been increasingly involved in the interpretation and enforcement of competition law. This gap in the literature is the main focus of the author's ongoing study on forensic IO economists and economics.

Concerning the second step of the inquiry, one could explore how interests outside the academic field impact on the evolution of economic thought and the standards of validity of economic knowledge in the industrial organization field. Certainly, this is not the first study of the important function interests play in the formation of scientific discourse. Barnes, among others, has challenged the conventional understanding of scientists as passively apprehending reality: "whatever the interests that guide knowledge generation, socially sustained consensus and a modification of existing meanings will always be involved in the process" ${ }^{\prime 40}$. Habermas also accepts that the validity of scientific knowledge is predetermined by specific knowledge constitutive interests $(\mathrm{KCI})$ in prediction and control, which vary according to each situation: different types of knowledge derived from the corresponding interests have different principles of validity ${ }^{141}$. This is particularly the case for economics, which shares a hybrid nature presenting the characteristics of both empirical-analytic knowledge and historical-hermeneutic knowledge, if one employs Habermas' categories ${ }^{142}$.

Under Barnes' conception, knowledge is primarily and always instrumental, "it is generated and evaluated in a way that is pre-organised by an interest in prediction and control, and normative, in the sense that it is sustained by a communal consensus which is decided, and not a rational necessity". These instrumental interests vary according to the specificities of each situation. Barnes suggests a "subjective, experimental approach" in identifying the operation of concealed interests. Yet this method fails to find a solution to the problem of imputation, that is, the association of specific beliefs or parts of knowledge to particular interests. In my view, this is extremely difficult to achieve and constitutes a fruitless enterprise, if one accepts that the same scientific knowledge used in different social contexts will respond to different interests. For example, the development of economic knowledge in an academic setting, might be seen as serving broadly the cognitive interests of

139 For some analysis of the "transnationalization" trend in economics see, however, M. Fourcade, 'The Construction of a Global Profession: The Transnationalization of Economics, (2006) 112(1) American Journal of Sociology, 145-194

$140 \quad$ B. Barnes, Interests and the Growth of Knowledge (Routledge, 1977), p. 18.

141 J. Habermas, Knowledge and Human Interests (Beacon Press, 1972).

142 This dual nature of modern economics is clearly illustrated by the following anecdote: An Indian born economist once explained his personal theory of reincarnation to his graduate economic class: 'if you are a good economist, a virtuous economist' he said 'you are reborn as a physicist. But if you are an evil, wicked economist, you are reborn as a sociologist': Paul Krugman, Peddling Prosperity: Economic Sense and Nonsense in the Age of Diminished Expectations (W. W. Norton \& Company, 1994), at xi. 
historical-hermeneutic knowledge, but also to a certain extent, if examined from the perspective of the professionalization process of economics, "academization" forming an initial step in this process in order to build the credibility and authority of economic knowledge, it might also be seen as serving an interest in technical control, characteristic of the empirical-analytic knowledge. Hence, focusing exclusively on the interests pursued by the scientific knowledge, does not provide a clear understanding of the evolution of the standards of validity in economics and alleged differences between "regulatory economics" and "academic economics".

A different strand of literature has focused on new knowledge production in a post-academic science setting. Current changes in scientific practice challenge the traditional conception of knowledge production as being located primarily in scientific institutions, such as Universities, and structured by scientific disciplines. Recent research has highlighted that scientific knowledge is increasingly the product of trans-disciplinary collaboration and takes place in a heterogeneous environment, where not only Universities, but also the public and the private sector contribute to knowledge production. Gibbons, Limoges, Nowotny, Schwartzman, Scott and Trow employed the term of Mode 2 knowledge to distinguish science produced in a "context of application", according to a "dialogic process" that incorporates multiple societal interests and institutions, such as universities, research centres, corporations, consultancies $^{143}$. Mode 2 knowledge is profoundly contextualised: for example, the traditional peer review systems of Mode 1 science are supplemented by additional criteria of economic, political, social and cultural nature. Mode 2 knowledge does not substitute but only complements Mode 1 knowledge. Nevertheless, its standards of validity are different. Some authors even claim that Mode 2 knowledge production illustrates a shift from "quality control" to "quality monitoring", a concept permitting the inclusion of new peers, such as users and lay persons, in the evaluation of knowledge and awarding greater consideration to the instrumental concerns of scientific knowledge, in the context of its application ${ }^{144}$.

Nevertheless, whatever is the name given to this description of the evolution of knowledge production ${ }^{145}$, Mode 2, "post-normal science", "Triple-Elix", "postacademic science", the general question of validity of the knowledge produced is not examined by this literature. As Ziman observes, the "meta-scientific spotlight has shifted to ethical issues", but in fine more general questions of validity of established scientific theories or the weight that should be given to a highly unorthodox scientific opinion remain largely unexplored ${ }^{146}$. A recent effort, by the Mode 2 knowledge promoters, to discuss the standards of validity of "contextualized science" has not

\footnotetext{
143 M. Gibbons, C. Limoges, H. Nowotny, S. Schwartzman, P. Scott, M. Trow, The New production of Knowledge: The Dynamics of Science and Research in Contemporary Societies (SAGE, 1994).

144 S. Hemlin \& S.B. Rasmussen, The shift in academic quality control, (2006) 31(2) Science Technology and Human Values 173-198.

145 See, for a literature review, L.K. Hessels, H. van Lente, Re-thinking new knowledge production: A Literature review and a research agenda, (2008) 37 Research Policy 740-760.

$146 \quad$ J. Ziman, Real Science: What It Is and What It Mean (Cambridge University press, 2002), p. 17.
} 
been convincing. Nowotny, Scott and Gibbons argue that "contextualized science" is the product of the increasingly close interaction between science and society ${ }^{147}$. Knowledge is produced in a new heterogeneous public space than the University, what they call "the agora", where society and science meet. With regard to the standards of validity of this new knowledge, they note the evolution from reliable knowledge to "socially robust knowledge". The latter is "relational" and "process oriented". No clear explanation is provided on what distinguishes this type of social robustness from the scientific robustness required for Mode 1 knowledge. Furthermore, they observe the emergence of socially distributed experts, coming from other parts of society that are active in the process of knowledge production and evaluation. Their claim for expertise is not only based on scientific reputation but on their ability to orchestrate the many heterogeneous and context-specific knowledge dimensions that are involved. Although the analysis provides useful insights, the volume is relatively poor on the criteria for judging when knowledge production in Mode 2 is robust and when it is not. The standards of validity of a theory or technique in "regulatory economics" are the product of a constant dialogic process with the standards of validity in "academic economics", an illustration of how the emergence of Mode 2 science leads to contextualized definitions of robustness and how the standards of validity of "academic economics" may sometimes be subject to those of "regulatory economics".

\section{Concluding remarks}

The field of economics has seen a profound transformation the last thirty years with the development of an active sub-field of practice, forensic economics, and its linkage with the legal system and the legal profession, more generally. The area of Industrial Organization, in particular, has seen a profound transformation from a purely academic and theoretical discipline to a professional endeavour with a broad field of practice in the areas of regulation and competition law. The area of welfare economics is also in the process of been transformed with the systematisation of cost benefit analysis and impact assessment in Europe, hence requiring a greater integration of economists in the evaluation of public policies, at both the government level and private practice. The role of the economist has gone from being merely complementary to become competing with that of another profession, much more organized and institutionally aware of its distinct role, that of lawyers. The relation between lawyers and forensic economists can be characterized as a form of coopetition, where they have to cooperate in order to provide the best service to their clients and represent them in courts and competition/regulatory authorities (the economists having a role of advocate manning the language of numbers, statistics and quantitative evidence), but also compete for rents, in the market for litigation services, as they need to share the fees paid by their clients for their legal/economic evidence

147 H. Nowotny, P. Scott, M. Gibbons, Re-thinking Science: Knowledge in an age of modernity (Polity, 2011). 
representation. Powerful economic consultancies, a more concentrated market than that of law firms in Europe, act as important agents for the representation of the interests of economists, in contrast with the more classic and old-style regulated profession of lawyers, whose institutional interests are represented by elected mostly institutions (the Bar Associations). Yet, these seem not to be in pace with the neoliberal emphasis on promoting competition and have increasingly incurred difficulties with their positioning in the public space, in view of the recent efforts of liberalization of professions and the dislocation of professions regulation. The emergence of forensic economics has important implications on the production of knowledge in economics and the interaction between heterodoxy and the mainstream in economic thought.

One should not forget that forensic economists have a dual/hybrid function. At some regards they operate as advocates, their interests being those of their clients, as lawyers usually do ("the market sphere"). However, they are also operating as "scientists", academics or intellectuals ("the intellectual sphere") where they produce "economic knowledge". It is also generally accepted that "the reception, survival and diffusion of intellectual products - whether as research programmes, theories, concepts and propositions - depends not just on the intrinsic arguments proposed or the strength of the evidence provided, but also on the range of rhetorical devices which the authors employ to locate themselves (and position others) within the intellectual and political field" ${ }^{\prime 48}$. An intellectual intervention, be it at an article published in an academic journal or economic testimony in a legal brief, does not have "an intrinsic meaning as such; it acquires its meaning in a particular setting; it is dependent on the status, position and trajectory of the author(s) and on the other intellectual products available at the time"149. As Baert explains: "effective positioning might help to diffuse the ideas or it might help the agent's career and material prospects", as it might also have adverse effects ${ }^{150}$. Yet, the integration of this double "milieu" of forensic economists in conceptualizing their work and in particular their "positioning" with regard to other agents operating in a particular context has been largely ignored by the literature. By focusing on the effects of forensic economists' interventions in the field of economics (intellectual sphere), positioning theory might offer a useful tool in order to understand the process of knowledge creation in the post-academic "science" of economics.

\footnotetext{
${ }^{148}$ P. Baert, 'Positioning Theory and Intellectual Interventions' (2012) Journal for the Theory of Social Behaviour (forth.) 1-21, at 1.

${ }^{149}$ Ibid.

${ }^{150}$ Ibid., p. 8.
} 